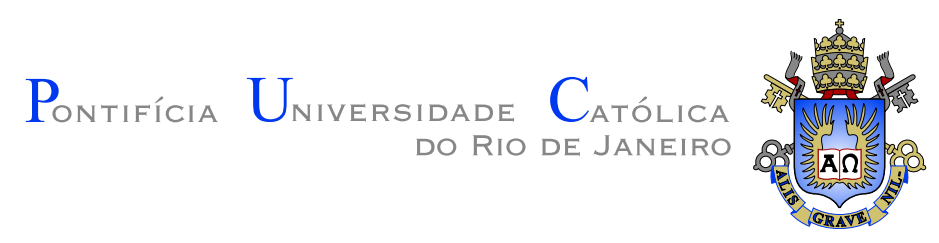

Daniela Alonso Fontes

\title{
Three Essays Using Home and Kitchen Appliances Sales Data
}

Tese de Doutorado

Thesis presented to the Postgraduate Program in Economics of the Departamento de Economia, PUC-Rio as partial fulfillment of the requirements for the degree of Doutor em Economia

Advisor: Prof. Leonardo Bandeira Rezende 


\section{Daniela Alonso Fontes}

\section{Three Essays Using Home and Kitchen Appliances Sales Data}

Thesis presented to the Postgraduate Program in Economics of the Departamento de Economia, PUC-Rio as partial fulfillment of the requirements for the degree of Doutor em Economia. Approved by the following commission:

Prof. Leonardo Bandeira Rezende

Advisor

Departamento de Economia - PUC-Rio

Prof. Tatiana Mercier Querido Farina

Insper Instituto de Ensino e Pesquisa

Prof. Juliano Assunção

Departmento de Economia - PUC-Rio

Prof. Gustavo Gonzaga

Departmento de Economia - PUC-Rio

Prof. Eduardo Pedral Sampaio Fiuza

Instituto de Pesquisa Econômica Aplicada - IPEA

Prof. Mônica Herz

Coordinator of the Centro de Ciências Sociais - PUC-Rio

Rio de Janeiro - December 7, 2012 
All rights reserved.

\section{Daniela Alonso Fontes}

Daniela holds a BA in economics from PUC-Rio and a MSc in economics from London School of Economics and Political Sciences. The primary focus of her research is industrial organization. She is currently a lecturer at the Department of Economics at PUC-Rio.

Bibliographic data

Fontes, Daniela Alonso

Three Essays Using Home and Kitchen Appliances Sales

Data / Daniela Alonso Fontes ; advisor: Leonardo Bandeira Rezende. - 2012.

76 f. : il. ; $30 \mathrm{~cm}$

Tese (Doutorado em Economia)-Pontifícia Universidade Católica do Rio de Janeiro, Rio de Janeiro, 2012.

Inclui bibliografia

1. Economia - Teses. 2. Eletroeletrônicos; Delegação de Autoridade; Informação assimétrica; Calote; Repasse de imposto para os preços.. I. Rezende, Leonardo Bandeira. II. Pontifícia Universidade Católica do Rio de Janeiro. Departamento de Economia. III. Título. 
To Henrique, Victoria and Eduardo, for turning the conclusion of this work more difficult and my life happier. 


\section{Acknowledgments}

To Leonardo Bandeira Rezende for his support, orientation and incentive and to Frederico Lundgren for making this work possible.

To Dilson Santos, Marcia Lima Cardoso, Rogério Marques, Edna Kohigashi and Rafael Santinelli for their help and enlightenment.

To Luiz Miguel Lee Lau for his essential help on preparing the data base and for his patience and availability.

To Capes and to CNPq for financial support.

To my parents, my brother and my husband for support and love.

To my colleagues, especially Rudi, Arnildo, Isabelle, Joana, and Marcelo, for their friendship that made the work easier.

To the members of the thesis committee for their comments and suggestions.

To the department's faculty and administrative assistants that helped me on this journey. 


\section{Abstract}

Fontes, Daniela Alonso; Rezende, Leonardo Bandeira (Advisor) Three

Essays Using Home and Kitchen Appliances Sales Data. Rio de Janeiro, 2012. 76p. Tese de Doutorado - Departamento de Economia, Pontifícia Universidade Católica do Rio de Janeiro.

This dissertation is composed of three independent empirical articles that use data on home and kitchen appliances and image equipment sales of one specific chain store and their clients' characteristics. The first one investigates the effect of the client's characteristics, such as gender, age, education and income, on the probability of receiving a discount. It intends to investigate if the pricing authority that is delegated to the salespeople is being well used. If the effect of delegation were to implement price discrimination, clients with higher income would have a lower probability of getting a discount. On the other hand, discounts can be given for a different reason than the one desired by the firm. Once the customer recognizes that the salesperson has some discretion over the prices, she may wish to engage in bargaining to decrease the final price. The outcome of this process may also depend on the customer's characteristics if they affect the customer's skill in bargaining. In this case, the greater the client's ability, the bigger the discount. Since we find that the probability of receiving a discount is increasing in the client's income and education, and the value of the discount is also bigger for people with higher income and better education, we conclude that the discount giving is not a result of price discrimination, but a result of a bargaining process. The second article estimates the effect of asymmetric information on consumer loans, using the payment plan chosen by the client and his observable characteristics. We decompose the effect into an adverse selection and a causal component using a technique similar to Adams, Einav and Levin (2009). We find significant marginal effects for both components and that the causal effect of the payment plan choice is greater than the one caused by the adverse selection. A key aspect of the identification strategy is the choice of the exogenous variable. We use a dummy variable that is one when the month of the purchase is one of the "saldão" months, that is, when one special payment plan is also available: eleven monthly payments, with zero interest rate. The variable used clearly influences the payment plan choice but the repayment behavior does not depend directly on it, since it is not directly related to the value of the debt collateral. The third article studies the retail market effects of the first tax stimulus episode of 2009, when the government reduced the IPI (Industrialized Products Tax) of certain categories of kitchen and home appliances. Tax rates vary depending on the product. The reduction occurred to four different products: refrigerators, stoves, washing machines and non 
automatic washing machines. We estimate the effect of the IPI reduction on prices and the composition of demand. We find that the IPI reduction lead to a $5.97 \%$ reduction on price, when we use a simple linear model and a $2.98 \%$ reduction, when we control for product fixed effects. The characteristics of consumers who acquire the appliances do not change significantly with the reduction.

\section{Keywords}

Kitchen and home appliances; Delegating price authority; Asymmetric information; Default; Pass through. 


\section{Resumo}

Fontes, Daniela Alonso; Rezende, Leonardo Bandeira (Orientador) Três Ensaios Usando Dados de Vendas de Eletroeletrônicos. Rio de Janeiro, 2012. 76p. Tese de Doutorado - Departamento de Economia, Pontifícia Universidade Católica do Rio de Janeiro.

Esta tese é composta por três artigos empíricos que utilizam dados de venda de uma cadeia de lojas de produtos eletroeletrônicos e de características de seus clientes. O primeiro investiga o efeito de características, como gênero, idade, escolaridade e renda, na probabilidade do cliente de receber desconto. Ele tem o objetivo de averiguar se a autoridade de decisão de preço final dada aos vendedores está sendo bem usada. Quando há discriminação de preços, clientes com renda mais alta devem ter menor probabilidade de receber descontos. Por outro lado, descontos podem ser dados por outros motivos, diferentes daquele desejado pela firma. Uma vez que o cliente percebe que o vendedor tem poder de decisão sobre o preço final, ele pode desejar começar um processo de barganha para reduzir o preço que pagará. O resultado deste processo pode também depender das características do cliente, se estas afetarem a habilidade de barganhar. Neste caso, quanto maior a habilidade do cliente de barganhar pelo desconto, maior este será. Como encontramos que a probabilidade de receber descontos aumenta com a renda e escolaridade do cliente, e o valor do desconto também é maior para pessoas com mais alta renda e mais educadas, concluímos que o desconto não está sendo dado como resultado de discriminação de preços, mas como o resultado de uma barganha. O segundo artigo estima o efeito de informação assimétrica sobre o financiamento da compra de produtos, usando o plano de pagamento escolhido e as características não observadas do cliente. Decompomos o efeito em seleção adversa e um componente causal, usando técnica similar à usada por Adams, Eivan and Levin (2009). Encontramos um efeito marginal significante e concluímos que o efeito causal da escolha do plano de pagamento é maior que aquele causado pela seleção adversa. Um aspecto chave da estratégia de identificação é a escolha da variável exógena. Usamos uma variável binária que é um quando a compra é feita num mês de "saldão", meses estes quando há um plano especial: onze parcelas sem juros. A variável usada claramente influencia a escolha do plano de pagamento, mas o repagamento não depende diretamente dela, uma vez que nosso instrumento não está associado ao valor do colateral do empréstimo. O terceiro artigo estuda o repasse para os preços da primeira redução de IPI de 2009. A redução ocorreu para quatro diferentes produtos: refrigeradores, fogões, máquinas de lavar e tanquinhos. Observamos o efeito do IPI nos preços e nas características dos clientes. Encontramos que a ocorrência da redução do IPI gera uma redução de 5,97\% no preço, quando 
usamos um modelo linear simples e uma redução de 2,98\% no preço, quando usamos um efeito fixo de produto. Gênero, idade, renda e escolaridade dos clientes que compram eletrodomésticos não mudam significativamente com a redução do IPI.

\section{Palavras-chave}

Eletroeletrônicos; Delegação de Autoridade; Informação assimétrica; Calote; Repasse de imposto para os preços. 


\section{Contents}

1 Is Pricing Authority Delegation Effective to Implement Price Discrimination?

1.1 Price Discounts in a Brazilian Retail Store $\quad 15$

1.2 Data 15

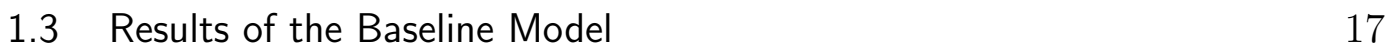

$\begin{array}{lll}1.4 & \text { Results of the Product Quantity Model } & 18\end{array}$

1.5 Results of the Payment Plan Model 20

1.6 Results of the Product Quality Model 23

1.7 Discount Value 24

$\begin{array}{lll}1.8 \text { Conclusion } & 26\end{array}$

2 The Effects of the Payment Plan Choice and the Non Observable Characteristics on Default Probability $\quad 40$

2.1 Data 42

2.2 Choice of The Exogenous Variable: "Saldão" and Non "Saldão" Months 44

2.3 Estimation: Understanding the Residual 46

2.4 Results 47

2.5 Different Choice Variable 48

2.6 Conclusion $\quad 50$

3 The Effect of Taxation on Prices and Sales of a Kitchen and Home Appliance Store $\quad \mathbf{6 6}$

$\begin{array}{lll}3.1 & \text { Data } & 67\end{array}$

3.2 The Industrialized Products Tax Stimulus 67

$\begin{array}{lll}3.3 & \text { Estimation } & 69\end{array}$

$\begin{array}{lll}3.4 & & 70\end{array}$

3.5 IPI Effect on Clients' Characteristics 70

$\begin{array}{lll}3.6 & \text { Conclusion } & 70\end{array}$ 


\section{List of Tables}

1.1 Descriptive Variables - Baseline Model 28

1.2 Descriptive Variables - Baseline Model, Per year 29

1.3 Descriptive Variables - Private Label Card 30

1.4 Probit Regression Result - Baseline 30

1.5 Probit Regression Result - Baseline with Product Quantities and Single Product Purchases 31

1.6 Probit Regression Result - Single Product Purchase Restricted Data Base 32

1.7 Down Payment and Interest Rate 33

1.8 Proportions of Number of Monthly Payments For EACH YEAR 34

1.9 Proportion of the Number of Monthly Payments With Zero Interest Rate, Per Year 35

1.10 Descriptive Variables - Restricted Data Base With the Payment Plan Variables, Private Label Card 35

1.11 Descriptive Variables - Single Product Payment Plan Model. 36

1.12 Probit Regression Result - Kitchen Appliances and SPECIFIC Product 37

1.13 Probit Regression Result - High and Low Price ProDUCTS 38

1.14 Linear Regression Result - Discount Value 39

2.1 Payment Plan Example 52

2.2 Descriptive Variables 52

2.3 Monthly Payments Occurrence 53

2.4 Monthly Payments Occurrence, When "Saldão" Month 54

2.5 Monthly Payment Occurrence, When not "Saldão" MONTH 55

2.6 Characteristics Difference When "Saldão" and Not "SALDÃO" 56

2.7 Interest Rate Regression Result - First Stage 57

2.8 Interest Rate Regression Result - Second Stage 58

2.9 Number of Monthly Payments Regression Result First Stage 59

2.10 Number of Monthly Payments Regression Result Second Stage 60

2.11 Average Marginal Effects Comparison 61

2.12 Interest Rate Regression Result - Second Stage Without the Non Observable 62

2.13 Interest Rate Regression Result - Second Stage Without the Interest Rate 63

2.14 Average Marginal Effects Comparison - Without THE Non OBSERVABLE 
2.15 Average Marginal Effects Comparison - Without Monthly Payments 65

3.1 IPI REDUCTION $\quad 72$

3.2 IPI TABLE $\quad 72$

3.3 Comparing Average Sales 72

3.4 Price Paid OLS and Fixed Effect Regression Results 73

3.5 Client's Characteristics Fixed Effect Regression RESULTS 


\section{Is Pricing Authority Delegation Effective to Implement Price Discrimination?}

This paper investigates empirically the effect of the client's characteristics on the probability of receiving a discount, using data from kitchen and home appliances and image equipment sales of a chain store and its client's characteristics. It intends to check if the pricing authority that is delegated to the salespeople is being well used. On one hand, salespeople may be better informed about clients' characteristics and delegation may be a way to implement price discrimination. On the other hand, the salesperson and the store have different objectives, and this may lead to discount patterns that do not increase the store's profits. If it was the first case, we would expect to find that clients with higher income have a lower probability of getting a discount. The results are robust to the choice of the empirical models. However, we find that the higher the income and the better the education, the higher the probability of receiving a discount. Therefore, we conclude that the discount giving pattern is not a result of price discrimination.

Whether retail stores should delegate to salespeople the authority to provide discounts is an important question in the marketing literature. According to Lal (1986), if information is symmetric, it does not matter if there is centralization or delegation. When the salesperson has more information about the clients' willingness to pay than the firm can get in its data base, delegation can be better than centralization. Joseph (2001) investigates a model where there is asymmetric information and an unobservable choice of effort by the salesperson. The best choice of delegation can be total or limited, depending on how the effort cost compares to the benefit of price discrimination. Even with symmetric information, Bhardwaj (2001) found that firms prefer to delegate when there is an intense price competition and to centralize when the effort competition is more intense. For every price competition level, there is an effort competition level where centralization is the first best. According to Mishra \& Prasad (2004) and Mishra \& Prasad (2005), when the salesperson can contract after knowing his private information, centralization is as good as delegation. For any competition intensity, there is always an equilibrium where centralization is better. 
One possible problem with price delegation is that the firm and the salesperson might have different incentives. Depending on the way compensation is designed, the salesperson can be more interested in selling the product no matter the final price, than in increasing the firm's profit. The argument against pricing authority delegation is exactly that the firm and the salesperson might have different incentives. To avoid that, in the case of asymmetric information in salespeople actions, there is the possibility to link salespeople compensation to sale margins, instead of volume. The salesperson, while maximizing his wage, maximizes the firm profit.

If delegation is effective in price discrimination, clients with higher income would have a lower probability of getting a discount, assuming that willingness to pay has a positive correlation to income. On the other hand, discounts can be given for a different reason than the one desired by the firm. Once the customer recognizes that the salesperson has some discretion over the prices, she may wish to engage in bargaining to decrease the final price. The outcome of this process may depend on the customer's characteristics, as well. She can have more talent to bargain than the salesperson. In this case, the greater the client's ability, the bigger the discount. Our second hypothesis is that more educated clients are more able to bargain, because we believe the ability to bargaining has a positive correlation to information and intelligence, which are correlated positively to education. Since this ability is not observable, we use education to represent it.

Since we find that the probability of receiving a discount is increasing in the client's income and education, and the value of the discount is also bigger for people with higher income and better education, we conclude that the discount giving is not a result of price discrimination, but a result of a bargaining process.

This result is compatible to what was found in Stephenson et al. (1979). They found that when the firm gives maximum authority to choose prices to salespeople, sales and profits decrease. Primeaux (1970) also concluded, after interviewing kitchen and home appliance selling firms, that the main reason for price differentiation of identical products is the buyer's bargaining capacity. We then can say that, in the case of that specific chain store, authority should not be delegated to salespeople.

Section 1.1 presents the firm and explains about its discounts and Section 1.2 describes the data base. Section 1.3 presents the results of the Baseline Model. Sections 1.4, 1.5 and 1.6 show the results of each particular case: Product Quantity, Payment Plan and Product Quality, respectively. Section 1.7 evaluates the discount as a value in Reais, instead of a binary variable. 
Finally, Section 1.8 concludes.

\subsection{Price Discounts in a Brazilian Retail Store}

The stores studied are part of a chain store located in seven different states in the South, Southeast and Central-West Regions, in Brazil. The stores sell kitchen and home appliances. There are around 280 stores. The standard consumer has an income between 260.00 and 1,800.00 Reais per month (These values were US $\$ 138.30$ and US $\$ 957,45$ on December, 31st, 2011).

In these stores, there are products with discounts decided by the firm and with discounts decided by the salesperson within a range determined by the store. Products with fixed discounts are typically small appliances, that can be bought in a self service basis. In the case of big appliances, it is necessary to talk to the salesperson and to fill out a form with client's data, including the address the product will be delivered. Those are the products which discount can be given by the salesperson.

In the kitchen and home appliance market, prices that are advertised are not the ones that will be paid. There is a manufacturer suggested retail price that must be the one announced by the firms. What is actually done is that, at the store, there are additional discounts announced. This kind of discounts are offered to any client who goes to that store.

In the firm we analyzed, the salesperson does not have full discretion over discounts. There is an upper bound decided by the firm. To provide incentives, the firm imposes a store-wide target average margin. Each store can decide how to distribute the total average margin, allowing different discounts for each sector. The person responsible for the sector, a coordinator or manager, decides how to distribute average target margins among the salespeople. Usually they all have the same average target. In the end, each salesperson can decide when to give a discount, as far as he respects his average margin limit. ${ }^{1}$

\subsection{Data}

We collected data from January 2006 to December 2009, from a kitchen and home appliance store $^{2}$. The data contains information on prices and

\footnotetext{
${ }^{1}$ To maximize profit, the firm chooses the maximum discount. To be sure that the selling price $\left(p_{i}\right)$ is high enough to compensate the salary and fixed costs, the firm calculates a fake marginal cost $\left(c_{i}\right)$. The salesperson knows the discount $\left(d_{i}\right)$ has to satisfy: $d_{i}<p_{i}-c_{i}$. Choosing the fake marginal cost is the same as choosing the discount upper bound $(\bar{d})$. Salesperson chooses the discount (between 0 and $\bar{d}$ ) that maximizes his salary. To provide incentives, salespeople compensation is always composed of a fixed wage and a variable part, that depends on their average margin. Therefore the salesperson faces a trade-off. On one hand, discounts increase the probability of selling. On the other hand, they decrease his wage.

${ }^{2}$ The chain store online sales are not considered.
} 
quantities from the individual purchases and clients' characteristics. Clients' characteristics are available because of the existence of a private label card and the necessity of filling out an application form when applying for it. For this reason we focus on purchases of clients that own the store private label card.

The private label card is not like a regular credit card. It is a card that allows the client to divide the payment of a purchase in monthly payments. It acts like a "crediário", a very common practice in Brazil. Unlikely a standard credit card, the owner of the card has to go to the store to pay all the partial payments, and the card can be used only to buy things in the stores of the same chain. Each card has a credit limit, that depends on the proved income and the history of the client as a debtor of the firm. In the case of the firm we are studying, the limit is related to the sum of partial payments of all the purchases done before, that have not been paid before.

The clients' characteristics available in the data set are: gender (female equals one), age (in years), education (equals one when the client has completed elementary or primary school called $1^{\text {st }}$ degree, secondary or high school called $2^{\text {nd }}$ degree and incomplete and complete college or university called $3^{\text {rd }}$ degree) and income (in 1,000 Reais).

Since we only observe the characteristics of the main card holder, we only use her purchases. This solution does not eliminate the possibility of the product being bought by someone else. That is the owner of the card can pay for it while someone else is responsible for the price negotiation. The hypotheses we need here are the following. First, it is not very common that one person decides about the purchase and another pays. And second, the person responsible for the negotiation and the one who pays have similar characteristics. She can be the main card holder's wife or a very close friend.

The dependent variable is the occurrence of discount, that is, we use a dummy variable, where one means the occurrence of discount, defined as discounts smaller than or equal to $10 \%$ and greater than zero. Bigger discounts are those given by the firm, not decided by the salesperson. This cut off was decided after talking to the firm managers, and taking into account the margin limit the firm imposes.

The products analyzed are in fact a subgroup of the totality of products sold at the store in question (they represented approximately $7.5 \%$ of the store's profits). The products considered are from three groups: kitchen appliance, home appliance and image equipment. The first group includes wine cellar, chimney kitchen cooker hood extractor, cook top, kitchen depurator, built-in cooker, freestanding cooker, electric oven, horizontal freezer, vertical freezer, fridge-bar, dishwasher, microwave, one door refrigerator, automatic 
defrost two doors refrigerator, frost free two doors refrigerator and side by side refrigerator. The second group includes wall air conditioning, split air conditioning, spin-dryer, conventional drying machine, electronic climate control, dehumidifying machine, automatic washing machine and semi-automatic washing machine. The image equipment group includes antenna, image cable, analogical converser, digital converser, dvd recorder, dvd player and karaoke, portable dvd, home theater, projector, tv rack, conventional television, lcd television, plasma television, slim television and vcr.

Tables 2.2 and 1.2 show some descriptive variables. There are more female than male clients, $63 \%$. The average age is 43 years old. Clients who went to the college (including those still in it) are only around 10 per cent. The majority has finished not only the primary school but also secondary school (54\% has the $2^{\text {nd }}$ degree). Average income is 1,126.40 Reais, per month. ${ }^{3}$ As said before, discounts are represented as dummy variables, where one is its occurrence. We can see from those tables that the proportions of discount are between $15.7 \%$ and $29.4 \%$.

Table 1.3 shows some descriptive variables when only purchases with the private label card are considered. When considering only purchases with the private label card, the proportion of discounts for the same period (from January 2006 to December 2009) is a little bit smaller: $19 \%$ versus $21 \%$. The proportion of females and average age are basically the same: $63 \%$ and 43 years, respectively. Average income is also very similar ( $\mathrm{R} \$ 1.12$ thousand Reais now and $\mathrm{R} \$ 1.13$ before) and education composition does not change significantly.

\subsection{Results of the Baseline Model}

We estimate, using a probit model, how the clients' characteristics increase the probability of receiving a discount, using as dependent variable the dummy of occurrence of discount.

We first include gender, age and education as the independent variables:

$$
\operatorname{Prob}\left(\operatorname{DiscOc}_{i j t}=1 \mid H, D\right)=\Phi\left(\beta_{0}+H_{i}^{\prime} \beta_{1}+D_{t}^{\prime} \beta_{2}\right)
$$

, where $\Phi$ is the cumulative normal distribution. DiscOc $c_{i j t}$ is the dummy variable that indicates the occurrence of discount when client $i$ buys the product $j$ at time $t . H_{i}$ is the vector of characteristics of client $i$ (do not change over time). It includes gender (1, when female), age (in years), age squared and education (dummy variables for $2^{\text {nd }}$ degree, $3^{\text {rd }}$ degree incomplete

${ }^{3}$ (This value was US\$600.49 on December, 31st, 2011. In 2011, the average national income was $1,345.00$ Reais or US $\$ 717.03$, using the same exchange rate) 
and $3^{\text {rd }}$ degree). $D_{t}$ is the vector of yearly dummy variables.

Table 1.4 shows the results of the baseline model. All the clients have a private label card but the purchase has not necessarily been made using this card. The probability of getting a discount is higher for more educated clients. A second degree diploma increases by 0.011 percentage points the probability of getting a discount. An incomplete third degree by 0.013 and a complete third degree by 0.017 . Since education and income are correlated we decided to add income to separate the two effects.

We regressed the same equation including gender, age and education as before but including also income. Now $H_{i}$, the vector of characteristics of client $i$, includes gender (1, when female), age (in years), age squared, education (dummy variables for $2^{\text {nd }}$ degree, $3^{\text {rd }}$ degree incomplete and $3^{\text {rd }}$ degree) and income (in 1,000 Reais).

Table 1.4 also shows the results when income is included. The database is the same as before and purchases can be done using any payment plan. The probability of receiving a discount is higher for clients with higher income. The probability of getting a discount is higher when the client has a second degree than when she has only a first degree. The marginal effects are positive for all education variables. Once we include income, the probability of getting a discount is not monotonic on education. This is not a problem. We did not expect that, separating the two effects, the difference on education level between someone with a $2^{\text {nd }}$ or $3^{\text {rd }}$ degree (complete or incomplete) would be monotonic. A second degree diploma increases by 0.032 percentage points the probability of getting a discount. An incomplete third degree by 0.031 and a complete third degree by 0.029 . An increase of a thousand Reais increases the probability of receiving a discount by 0.022 percentage points.

If price discrimination was occurring, we would expect to see clients with higher income having a lower probability of receiving a discount. As explained before, clients with higher income are those more willing to pay and those are the clients that could probably buy a product for a higher price. Since the results indicate that income increases the probability of getting a discount we conclude that the price discrimination occurring is the opposite that was intended by the firm.

\subsection{Results of the Product Quantity Model}

In this section we take into account the fact that more than one product can be bought together. It could be the case that buying more than one product together increases the probability of getting a discount. The probability of receiving a discount might increase with income because of the fact that richer 
clients tent to buy more products in a single purchase. First we include the number of products as an independent variable and then we consider only purchases of a single product.

$\operatorname{Prob}\left(\right.$ DiscOc $_{i j t}=1 \mid H, D$, Prodquant $)=\Phi\left(\beta_{0}+H_{i}^{\prime} \beta_{1}+D_{t}^{\prime} \beta_{2}+\right.$ Prodquant $_{i j t} \beta_{3}$ Pl-2 $\left._{1}\right)$

, where the variables are the same as before and Prodquant ${ }_{i j t}$ is how many products were bought in the purchase in question.

In fact, the number of products has a significant effect on the probability of receiving a discount. Table 1.5 shows the larger the quantity of products bought together, the higher is the probability of getting a discount. Buying one more product increases the probability of receiving a discount by 0.0925 percentage points.

All the average marginal effects have the same sign and are very similar to the ones we have before. People with higher income have higher probability of receiving a discount and the effects of having a degree have all positive signs.

Another way to test if our findings are a consequence of the fact that more than one product is being bough together, is to estimate the model for the sub-sample of only purchases of a single product. They are $83 \%$ of the total number of purchases in our database. Single Product means no other product from one of the three groups of products considered (kitchen appliance, home appliance, and image equipment) is bought together with the one in question.

Our data base covers only a subgroup of the totality of products sold at the store in question. This restriction could generate a small distortion because even knowing how many products of the two groups were bought together, we do not consider other products that could be bought but are part of a different product group. For example, if a customer buys a refrigerator and a hair dryer, we see as if he has bought just the fridge. We do not see this as a problem because, in terms of value, the products that are disregarded are much smaller than the ones considered. We do not believe that someone can gain a better discount when buying a television because has decided to buy together an iron. On the other hand, buying a dvd player or a home theater, together with a television, can influence the final price of the purchase.

Table 1.5 also reports the results under our baseline specification for the restricted sample with single product purchases. It shows that even if we consider only the purchases when only a single product is bough, the higher the income, the higher is the probability of getting a discount. However, the marginal effect is smaller 0.63 percentage points when all purchases are 
considered versus 0.58 percentage points for purchases of only a single product. We still have positive signs for education effects.

\subsection{Results of the Payment Plan Model}

If we take into account the fact that payments in currency or by check and the combination of several products in the same purchase might have an effect on the probability of getting a discount we still have other factors to affect discount giving that must be analyzed. It can be the case that, even if all the purchases considered are done using the store private label card, different payment plans induce to different probabilities of discount. That is, depending on how many partial payments or on the interest rate chosen, the probability of getting a discount could change. That would be the case that richer people could choose payment plans more attractive to the firm, for example.

Restricting the database to the one with payments using the private label card allow us to use data about the payment plan, that is, the interest rate paid, the financial plan (number of monthly payments, i.e., instalments) and the occurrence of down payment. The Down Payment is a dummy variable, which is one when the client pays it. Interest is the interest rate, per month, used to finance the purchase. And Monthly Payment is the number of monthly payments made.

In this section we estimate how the clients' characteristics increase the probability of receiving a discount, using again the dummy of occurrence of discount as dependent variable, the same characteristics of the clients as independent variables and including this time the payment plan variables. The effect of the payment plan chosen is explicitly showed, excluding the hypothesis that it is the reason for the probability of receiving a discount increase. But first, we estimate how the clients' characteristics increase the probability of receiving a discount, using the baseline specification one more time just restricting the database to purchases only made with the private label card and maintaining the restriction of a single product purchase. Before including the payment plan variables we want to analyze how much the results change when the private label card restriction is made.

Table 1.6 shows the results. We observe significance of all the clients' characteristics. If the person has completed the secondary school or has an university diploma, the probability of her receiving a discount is higher than if she has finished only the primary school. In this case, a high school diploma seems to induce a stronger effect on this probability. A complete university degree has a bigger effect than an incomplete one. The higher the income, the higher the probability of discount. 


\subsubsection{Payment Plan Description}

For each product offered there is a menu of financing plans available. These menus are the same for every store of the chain. They are decided according to the historical risk of default of each product. A product can be sold with a required down payment or not. The menus are the same for all buyers, i.e., there is no discrimination at this point. There are different combinations of number of partial payments and interest rates.

Table 1.7 shows the number of purchases with and without down payment for each year (2006-2009). It includes purchases with more than one product bought together. It is also possible to see how many of them were with interest and how many were not. Sometimes a down payment is required, sometimes not, depending on the product. In 2009, $65 \%$ of the total purchases were with a down payment. From these, $75 \%$ were without interest. When there was not a down payment, $82 \%$ of the purchases were with interest. The proportions in the other years were very similar.

Table 1.8 shows the frequencies of financed sales, by numbers of partial payments. The values of the monthly payments are fixed for all financing plans, i.e., the interest rate is included in the total amount that is divided in partial payments. We can see that there are choices concentrated in some numbers. This is expected, because everyone when paying without interest should choose the larger number of partial payments available.

Table 1.9 shows the proportion of number of partial payments chosen each year when there is no interest. The mode is 9 for all the years.

Table 1.10 is an extended form of Table 1.3. It shows descriptive variables when only purchases with the private label card are considered and includes the payment plan variables (not included before). As said before, the proportion of females, the average age, the average income and the education composition do not change significantly. Only the proportion of discounts is a little bit smaller: $19 \%$ versus $21 \%$, when considering only purchases with the private label card.

More than $70 \%$ of purchases included a down payment. The average interest is $2.03 \%$ per month when all purchases are considered, and $4.53 \%$ when only the positive interest rates are considered, which are $44.72 \%$ of the cases. The average number of payments chosen is 9.83 .

As we, in fact, ended up restricting to the purchases with only a single product we also have the descriptive variables for this case.

Table 1.11 shows the descriptive variables of the most restricted data base: purchases of one single product with the private label card. The means of the client's characteristics do not change significantly. Comparing to Tables 2.2, 1.3 and 1.10, we can see that females are around $63 \%$ in all cases and the 
age is 43 years, approximately. The proportion of education is also basically the same. The mean of the income decreases as we restrict (from 1.13 to 1.11 when restricting the payment plan and to 1.08 when restricting to a single product), and the variance also decreases. The payment plan variables are similar too: the occurrence of down payment is $70.18 \%$ versus $70.85 \%$ before, the average interest rate is $2.08 \%$ and was $2.03 \%$, the proportion of positive interest is $45.9 \%$ and was $45.5 \%$, the average interest rate when only positive numbers are considered is $4.52 \%$ versus $4.53 \%$ and the average number of partial payments is now 9.7 versus 9.8 , before.

\subsubsection{Including the Payment Plan Data}

Now we also include the payment plan variables, down payment, interest and monthly payments, as independent variables. The regression is the following.

$$
\operatorname{Prob}\left(\operatorname{DiscOc}_{i j t}=1 \mid X\right)=\Phi\left(\beta_{0}+H_{i}^{\prime} \beta_{1}+D_{t}^{\prime} \beta_{2}+\operatorname{Pag}_{i j t}^{\prime} \beta_{3}\right)
$$

, where $\Phi$ is the cumulative normal distribution. DiscO $c_{i j t}$ is the dummy variable that indicates the occurrence of discount when client $i$ buys the product $j$ at time $t . H_{i}$ is the vector of characteristics of client $i$. It includes gender (1, when female), age (in years), age squared, education (dummy variables for $2^{\text {nd }}$ degree, $3^{\text {rd }}$ degree incomplete and $3^{\text {rd }}$ degree) and income (in 1,000 Reais), as before. $D_{t}$ is the vector of yearly dummy variables. Pag $_{i j t}$ is the vector of the payment plan chosen by client $i$ for the product $j$ at time $t$ and it includes interest (per month), down payment (1, when occurs) and number of monthly payments.

Table 1.6 shows the results. We observe strong significance of the income marginal effect. The higher the income, the higher the probability of discount. The probability of getting a discount is higher for women. If the person has finished the secondary school or has completed the university, the probability of her receiving a discount is higher than if she has only the first degree. This effect increases as the education increases. That is, a university diploma induces a stronger effect on this probability than a secondary school diploma. To have studied and not completed the university has an intermediate effect.

The presence of the payment plan variables does not weaken the prior result. On the contrary: the education and income coefficients become bigger, the coefficients for education present the expected order. The coefficients for the payment plan variables are the expected ones. The probability of receiving 
a discount is higher the smaller is the number of partial payments and when there is a down payment. As the interest rate increases, the probability of getting a discount increases.

What we can see is that when we take into account the criticism about the payment plan chosen and restrict to a single product, estimates become more precise and the results become even stronger.

\subsection{Results of the Product Quality Model}

In this section we want to investigate if our findings are due to product heterogeneity. The reason to analyze product heterogeneity is that since people with higher income usually buy different products than those with less resources, it could be the case that the discount is given because of the quality of the product, rather than client's characteristics.

To observe how results vary with the quality of the products, we estimate the following sub-groups of purchases. For all the samples, we use the purchases of a single product, using the private label card and we also include the payment plan variables. The estimation procedure is the same as the last one, with the restriction that all purchases must be from the sub-group we are studying.

\subsubsection{Kitchen Appliances}

First we use only the products from the kitchen appliance sector. It includes cooker hoods, cookers, ovens, freezers, dishwashers, microwave ovens and refrigerators.

Table 1.12 shows the results of the kitchen appliance sector when purchases are of a single product and the payment plan variables are included. The education effects are again all positive. The probability of getting a discount is lower for women. The higher the income, the higher the probability of getting a discount. Again the payment plan effects have the expected signs.

Even restricting the products to kitchen appliances, we can conclude there is no price discrimination.

\subsubsection{High and Low Prices}

We divide the products into two groups. One with products which the prices are above 1,000.00 Reais, called high price products and another with prices below or equal to 1,000.00 Reais, called low price products.

Table 1.13 shows the results of high price products. We observe strong significance of both education and income and the marginal effects are all positive. The order of the education effects are the one we expected. The 
probability of getting a discount is lower for women, but its significance is weak. The payment plan variable effects have the same signs as before. We can notice that all effects have increased, but the one for down payment has increased more than the others. For high price products, the down payment occurrence marginal effect increases the probability of getting a discount with a greater magnitude.

Table 1.13 also shows the results of low price products. The income marginal effect is still significant and positive. The education effects are all positive and significant. The probability of getting a discount is higher for women. We have noticed that for high price products having a down payment was more important for increasing the probability of receiving a discount than when we considered all the products. For low price products, the effect is negative, that is, having a down payment decreases the probability of receiving a discount. The interest and number of monthly payments marginal effects have the same sign as the case with all products.

The probability of getting a discount is higher for people with higher income, no matter the product is an expensive or a cheap one. Even taking into account the fact that prices could influence the decision of giving a discount, the results still indicate it is not the case there is price discrimination as the firm would want it to be.

\subsubsection{Specific Product}

The robustness of the results when restricting to one sector and dividing into two price ranges indicates that the higher the income the higher the probability of discount. To be even more strict we narrow the sample to one random specific type of product: defrost and frost free two doors refrigerator below or equal to 400 liters.

The results are in Table 1.12. Both the income and the education marginal effects are positive and significant. The order for education marginal effects is the expected one. The effect for gender is positive. The payment plan marginal effects also have the expected signs. One more time we find a result that is not compatible with price discrimination.

\subsection{Discount Value}

We also want to see what happens when instead of considering the discounts as a binary variable, we consider the discount value, in Reais. We use the database of purchases of a single product, made with the private label card. We restrict the database considering only the purchases when there is a discount given by the salesperson, that is we use a limited data base. The 
sales without discount or with the big discounts given by the store are not considered.

We estimate the following model, using OLS.

$$
\text { Discountvalue }_{i j t}=\beta_{0}+H_{i}^{\prime} \beta_{1}+D_{t}^{\prime} \beta_{2}+\operatorname{Pag}_{i j t}^{\prime} \beta_{3}+\epsilon_{i j t}
$$

, where Discountvalue $_{i j t}$ is the value of the discount, in Reais, when client $i$ buys the product $j$ at time $t . H_{i}$ is the vector of characteristics of client $i$ (do not change). It includes gender (1, when female), age (in years), age squared, education (dummy variables for $2^{\text {nd }}$ degree, $3^{\text {rd }}$ degree incomplete and $3^{\text {rd }}$ degree) and income (in 1,000 Reais). $D_{t}$ is the vector of yearly dummy variables. Pag $_{i j t}$ is the vector of the payment plan chosen by client $i$ for the product $j$ at time $t$ and it includes interest (per month), down payment (1, when occurs) and number of monthly payments. $\epsilon_{i j t}$ is the zero mean idiosyncratic error.

Table 1.14 shows the results of a linear regression of the discount value (of the limited data base) on the client's characteristics and payment plan variables we used before. The results regarding the client's characteristics are similar to the findings from the probit analysis. The education and income coefficients are positive, significant and have the right order. The gender (women) coefficient is negative and significant, and has smaller magnitude than all the education and income effects.

When we look at the payment plan variables, we find the following results: buying a product with a down payment has a positive effect on the value of the discount given by the salesperson, the higher the interest paid, the smaller the discount value and the larger the number of partial payments, the bigger the discount value. Hence, although higher interest rate increases the probability of receiving a discount, it decreases the value of the discount given. On the other hand, the increase of the number of payments decreases this probability but increases the value of the discount.

We then consider the complete database, first including all the discounts (not only the discounts given by the salesperson). The estimated model is the same.

Table 1.14 also shows the results of a linear regression of the discount value (of the complete data base) on the client's characteristics and payment plan variables. The coefficients are different from the ones of the limited data base but the main findings are still the same: the education and income coefficients are positive, significant and have the right order, the gender 
coefficient is negative and significant, and has smaller magnitude than all the education and income effects, buying a product with a down payment has a positive effect on the value of the discount, the higher the interest paid, the smaller the discount value and the larger the number of partial payments, the bigger the discount value.

Finally, instead of censoring the sample, we truncated it. Discounts greater than $10 \%$ were recorded as zero discount. Remember those are discounts given by the firm, not the salesperson. The model is again the same as before.

Table 1.14 shows the results of a linear regression of the truncated discount value on the client's characteristics and payment plan variables. The results are similar to the limited and complete data base, except for the interest coefficient that is now positive.

Under all specifications, income and education are associated with larger discount values.

\subsection{Conclusion}

We investigated empirically the effect of the client's characteristics on the probability of receiving a discount, using data from kitchen appliance, home appliance and image equipment sales of a chain store and its client's characteristics. The dependent variable was a dummy of occurrence of discount. We intended to check if the pricing authority that is delegated to the salespeople is being well used.

First we constructed a baseline model, where the data used included all purchases of the clients that had a store private label. The independent variables were the client's characteristics. If the salespeople were providing discounts in order to price discriminate, we would expect that clients with higher income would have a lower probability of receiving a discount. We found the opposite.

Then we constructed different robustness checks taking into account different possible explanations for the result. Using the same data, we included the number of products as an additional independent variable, as it could be the case that buying more than one product together increased the probability of getting a discount. We found that the larger the number of products bought together, the higher is the probability of getting a discount. The data were then restricted to purchases where only a single product was bought. After that, we restricted again the data, considering only payments made using the store private label card, eliminating payments in currency or by check. This eliminated discounts given because of the payment form chosen. We then included the payment plan variables, that is, the interest paid, the financial 
plan (number of monthly payments, i.e., instalments) and the occurrence of down payment, because the payment plan chosen could also be responsible for the different probabilities. Then to be able to eliminate the explanation that the discount pattern found was due to product quality, we did some exercises for product characteristics. We estimated four different subgroups. The first, included only the products from the kitchen appliance sector. The second and the third, separated products which the prices were above 1,000.00 Reais, called high prices and products with prices below or equal to 1,000.00 Reais, called low prices, respectively. And the fourth, included only the purchases of one specific random type of product: defrost and frost free two doors refrigerator below or equal to 400 liters. We found very robust results: for all different models, the higher the income and the better the education, the higher the probability of discount.

We also investigated what would happen when, instead of considering the discounts as a binary variable, we considered the discount value, in Reais. We used three different samples. The first was a restricted one. Only purchases with discounts given by the salespeople were considered, in other words, the sales without discount or with bigger discounts, given by the store were discarded. The second one was the complete database. The third one is a truncated sample, that is, the discounts greater than $10 \%$ were substituted by zero discount. We found some interesting results about the payment plan variables, but the results were similar to those that were found in the probit analysis when we look to the characteristics: the education and income coefficients are positive, significant and have the right order, for the three cases. The conclusion is that not only the probability of receiving a discount is higher for clients with higher income, but also the value, in Reais, of the discount is bigger.

Since we find that the probability of receiving a discount is increasing in the client's income and the value of the discount is also bigger for people with higher income we conclude that price delegation is not being effectively used for price discrimination. The discount pattern observed may be the outcome of bargaining between clients and salespeople. It could also be a long term strategy to gain clients' loyalty or a result of a more elastic demand. The firsts hypothesis is supported by the fact that both the probability of receiving a discount and the value of the discount given increase with education: it seems that the clients that receive discounts are those that are able to ask for them, not those that need them to make the purchase. 
Table 1.1: Descriptive Variables - Baseline Model Description of the variables. All kinds of payment plan. Purchases made by the main card holder, from January 2006 to December 2009.

\begin{tabular}{|c|c|c|c|}
\hline Variable & Explanation & Mean & Standard Error \\
\hline DiscOc & proportion of discounts & 0.2138 & - \\
\hline Gender & proportion of females & 0.6332 & - \\
\hline Age & in years & 42.7440 & 14.0814 \\
\hline Education1dg & proportion $1^{s t}$ degree & 0.3508 & - \\
\hline Education2dg & proportion $2^{n d}$ degree & 0.5410 & - \\
\hline Education3inc & pp. $3^{\text {rd }}$ degree incomplete & 0.0307 & - \\
\hline Education3dg & proportion $3^{r d}$ degree & 0.0774 & - \\
\hline Income & in 1,000 Reais & 1.1264 & 1.0147 \\
\hline
\end{tabular}


Table 1.2: Descriptive Variables - Baseline Model, Per year Description of the variables. All kinds of payment plan. Purchases made by the titular, from January 2006 to December 2009.

\begin{tabular}{|c|c|c|c|}
\hline Variable & Explanation & Mean & Standard Error \\
\hline DiscOc2006 & proportion of discounts & 0.2056 & - \\
\hline DiscOc2007 & proportion of discounts & 0.2008 & - \\
\hline DiscOc2008 & proportion of discounts & 0.1570 & - \\
\hline DiscOc2009 & proportion of discounts & 0.2937 & - \\
\hline Gender2006 & proportion of females & 0.6278 & - \\
\hline Gender2007 & proportion of females & 0.6340 & - \\
\hline Gender2008 & proportion of females & 0.6331 & - \\
\hline Gender2009 & proportion of females & 0.6371 & - \\
\hline Age2006 & in years & 43.3402 & 13.7407 \\
\hline Age2007 & in years & 42.9806 & 14.0527 \\
\hline Age2008 & in years & 42.2846 & 14.1092 \\
\hline Age2009 & in years & 42.4621 & 14.3528 \\
\hline Education1dg2006 & proportion $1^{s t}$ degree & 0.3416 & - \\
\hline Education1dg2007 & proportion $1^{\text {st }}$ degree & 0.3601 & - \\
\hline Education1dg2008 & proportion $1^{\text {st }}$ degree & 0.3527 & - \\
\hline Education1dg2009 & proportion $1^{s t}$ degree & 0.3478 & - \\
\hline Education2dg2006 & proportion $2^{\text {nd }}$ degree & 0.5478 & - \\
\hline Education2dg2007 & proportion $2^{\text {nd }}$ degree & 0.5360 & - \\
\hline Education2dg2008 & proportion $2^{\text {nd }}$ degree & 0.5395 & - \\
\hline Education2dg2009 & proportion $2^{\text {nd }}$ degree & 0.5418 & - \\
\hline Education3inc2006 & pp. $3^{r d}$ degree incomplete & 0.0283 & - \\
\hline Education3inc2007 & pp. $3^{r d}$ degree incomplete & 0.0298 & - \\
\hline Education3inc2008 & pp. $3^{r d}$ degree incomplete & 0.0320 & - \\
\hline Education3inc2009 & pp. $3^{r d}$ degree incomplete & 0.0324 & - \\
\hline Education3dg2006 & proportion $3^{r d}$ degree & 0.0824 & - \\
\hline Education3dg2007 & proportion $3^{r d}$ degree & 0.0741 & - \\
\hline Education3dg2008 & proportion $3^{r d}$ degree & 0.0758 & - \\
\hline Education3dg2009 & proportion $3^{r d}$ degree & 0.0780 & - \\
\hline Income2006 & in 1,000 Reais & 1.1740 & 1.0515 \\
\hline Income2007 & in 1,000 Reais & 1.1081 & 1.0118 \\
\hline Income2008 & in 1,000 Reais & 1.1094 & 1.0084 \\
\hline Income2009 & in 1,000 Reais & 1.1203 & 0.9895 \\
\hline
\end{tabular}


Table 1.3: Descriptive Variables - Private Label Card

Description of the variables. Purchases made with the private label card, by the titular, from January 2006 to December 2009.

\begin{tabular}{cccc}
\hline \hline Variable & Explanation & Mean & Standard Error \\
\hline \hline DiscOc & proportion of discounts & 0.1925 & - \\
\hline Gender & proportion of females & 0.6257 & - \\
Age & in years & 42.5887 & 14.0389 \\
Education1dg & proportion 1 $1^{\text {st }}$ degree & 0.3558 & - \\
Education2dg & proportion 2 $2^{\text {nd }}$ degree & 0.5386 & - \\
Education3in & pp.3 $3^{\text {rd }}$ degree incomplete & 0.0303 & - \\
Education3dg & proportion 3 $3^{\text {rd }}$ degree & 0.0754 & - \\
Income & in 1,000 Reais & 1.1150 & 0.9871 \\
\hline \hline
\end{tabular}

Table 1.4: Probit Regression Result - Baseline

Results of the regression of the occurrence of discounts, using the total data base, on the clients' characteristics. Coefficient and average marginal effects. Gender (1, when female), age (in years), age squared, education (dummy variables for $2^{\text {nd }}$ degree, $3^{\text {rd }}$ degree incomplete and $3^{\text {rd }}$ degree), income (in 1,000 Reais) and yearly dummies. Robust standard errors in parentheses. Significance: ${ }^{* * *} \mathrm{p}<0.01 ;{ }^{* *} \mathrm{p}<0.05$ and ${ }^{*} \mathrm{p}<0.1$.

\begin{tabular}{ccccc}
\hline \hline Variable & Coefficient & Marginal Effects & Coefficient & Marginal Effects \\
\hline \hline Constant & $-0.889485^{* * *}$ & - & $-0.885676^{* * *}$ & - \\
& $(0.009278)$ & - & $(0.009279)$ & - \\
Gender & -0.000845 & -0.000242 & $0.007784^{* * *}$ & $0.002230^{* * *}$ \\
& $(0.001999)$ & $(0.000573)$ & $(0.002035)$ & $(0.000583)$ \\
Age & -0.000487 & -0.000140 & $-0.001471^{* * *}$ & $-0.000422^{* * *}$ \\
& $(0.000391)$ & $(0.000112)$ & $(0.000393)$ & $(0.000113)$ \\
Age Squared & $0.000030^{* * *}$ & $0.000008^{* * *}$ & $0.000036^{* * *}$ & $0.000010^{* * *}$ \\
& $(0.000004)$ & $(0.000001)$ & $(0.000004)$ & $(0.000001)$ \\
Education2dg & $0.039793^{* * *}$ & $0.011396^{* * *}$ & $0.032120^{* * *}$ & $0.009199^{* * *}$ \\
& $(0.002168)$ & $(0.000620)$ & $(0.002196)$ & $(0.000628)$ \\
Education3inc & $0.045452^{* * *}$ & $0.013249^{* * *}$ & $0.031319^{* * *}$ & $0.009081^{* * *}$ \\
& $(0.005843)$ & $(0.001731)$ & $(0.005877)$ & $(0.001723)$ \\
Education3dg & $0.056837^{* * *}$ & $0.016602^{* * *}$ & $0.028697^{* * *}$ & $0.008305^{* * *}$ \\
& $(0.003824)$ & $(0.001137)$ & $(0.004032)$ & $(0.001178)$ \\
Income & - & - & $0.022041^{* * *}$ & $0.006319^{* * *}$ \\
& - & - & $(0.000996)$ & $(0.000286)$ \\
D2007 & $-0.015635^{* * *}$ & $-0.004471^{* * *}$ & $-0.014736^{* * *}$ & $-0.004213^{* * *}$ \\
& $(0.002788)$ & $(0.000795)$ & $(0.002788)$ & $(0.000795)$ \\
D2008 & $-0.182555^{* * *}$ & $-0.050671^{* * *}$ & $-0.181907^{* * *}$ & $-0.050485^{* * *}$ \\
& $(0.002835)$ & $(0.000759)$ & $(0.002836)$ & $(0.000759)$ \\
D2009 & $0.281179^{* * *}$ & $0.085296^{* * *}$ & $0.281821^{* * *}$ & $0.085482^{* * *}$ \\
& $(0.002696)$ & $(0.000857)$ & $(0.002696)$ & $(0.000857)$ \\
\hline \hline Pseudo R2 & 0.0148 & & 0.0148 & \\
Obs Number & $2,187,533$ & & $2,187,533$ & \\
\hline \hline
\end{tabular}


Table 1.5: Probit Regression Result - Baseline with Product Quantities and Single Product Purchases

Results of the regression of the occurrence of discounts, using the total data base, on the clients' characteristics and the product quantity and using only purchases of a single product, on the clients' characteristics. Coefficients and average marginal effects. Gender (1, when female), age (in years), age squared, education (dummy variables for $2^{\text {nd }}$ degree, $3^{\text {rd }}$ degree incomplete and $3^{\text {rd }}$ degree), income (in 1,000 Reais), yearly dummies and product quantities. Robust standard errors in parentheses. Significance: ${ }^{* * *} \mathrm{p}<0.01 ;{ }^{* *} \mathrm{p}<0.05$ and ${ }^{*} \mathrm{p}<0.1$.

\begin{tabular}{ccccc}
\hline \hline Data Base & \multicolumn{2}{c}{ Total Data Base } & \multicolumn{2}{c}{ Single Product } \\
Variable & Coefficient & Marginal Effects & Coefficient & Marginal Effects \\
\hline \hline Constant & $-0.889190^{* * *}$ & - & $-0.894954^{* * *}$ & - \\
& $(0.009459)$ & - & $(0.010100)$ & - \\
Gender & $0.007758^{* * *}$ & $0.002222^{* * *}$ & $0.010963^{* * *}$ & $0.003148^{* * *}$ \\
& $(0.002035)$ & $(0.000583)$ & $(0.002223)$ & $(0.000637)$ \\
Age & $-0.001476^{* * *}$ & $-0.000423^{* * *}$ & $-0.000990^{* *}$ & $-0.000285^{* *}$ \\
& $(0.000393)$ & $(0.000113)$ & $(0.000427)$ & $(0.000123)$ \\
Age Squared & $0.000036^{* * *}$ & $0.000010^{* * *}$ & $0.000033^{* * *}$ & $0.000009^{* * *}$ \\
& $(0.000004)$ & $(0.000001)$ & $(0.000004)$ & $(0.000001)$ \\
Education2dg & $0.032088^{* * *}$ & $0.009190^{* * *}$ & $0.031904^{* * *}$ & $0.009162^{* * *}$ \\
& $(0.002196)$ & $(0.000628)$ & $(0.002388)$ & $(0.000685)$ \\
Education3inc & $0.031190^{* * *}$ & $0.009044^{* * *}$ & $0.026024^{* * *}$ & $0.007552^{* * *}$ \\
& $(0.005877)$ & $(0.001723)$ & $(0.006478)$ & $(0.001897)$ \\
Education3dg & $0.028581^{* * *}$ & $0.008271^{* * *}$ & $0.025352^{* * *}$ & $0.007349^{* * *}$ \\
& $(0.004032)$ & $(0.001178)$ & $(0.004497)$ & $(0.001315)$ \\
Income & $0.021842^{* * *}$ & $0.006262^{* * *}$ & $0.020245^{* * *}$ & $0.005820^{* * *}$ \\
& $(0.001002)$ & $(0.000287)$ & $(0.001153)$ & $(0.000331)$ \\
D2007 & $-0.014793^{* * *}$ & $-0.004229^{* * *}$ & $-0.022338^{* * *}$ & $-0.006395^{* * *}$ \\
& $(0.002789)$ & $(0.000795)$ & $(0.003065)$ & $(0.000874)$ \\
D2008 & $-0.181963^{* * *}$ & $-0.050500^{* * *}$ & $-0.179208^{* * *}$ & $-0.049881^{* * *}$ \\
& $(0.002836)$ & $(0.000759)$ & $(0.003107)$ & $(0.000834)$ \\
D2009 & $0.281935^{* * *}$ & $0.085518^{* * *}$ & $0.275826^{* * *}$ & $0.083632^{* * *}$ \\
& $(0.002697)$ & $(0.000857)$ & $(0.002927)$ & $(0.000928)$ \\
Prod Quantity & $0.003225^{*}$ & $0.000925^{*}$ & - & - \\
& $(0.001705)$ & $(0.000489)$ & - & - \\
\hline \hline Pseudo R2 & 0.0150 & & 0.0148 & \\
\hline \hline
\end{tabular}




\section{Table 1.6: Probit Regression Result - Single Product Purchase Restricted Data BASE}

Results of the general regression of the occurrence of discounts, using the restrict data base, on the clients' characteristics and, as explained in Section 1.2, on the clients' characteristics and the payment plan variables. Coefficients and average marginal effects. Gender (1, when female), age (in years), age squared, education (dummy variables for $2^{\text {nd }}$ degree, $3^{\text {rd }}$ degree incomplete and $3^{\text {rd }}$ degree), income (in 1,000 Reais), yearly dummies and payment plan variables (down payment dummy, interest rate and number of monthly payments). Robust standard errors in parentheses. Significance: ${ }^{* * *} \mathrm{p}<0.01{ }^{* *} \mathrm{p}<0.05$ and ${ }^{*} \mathrm{p}<0.1$.

\begin{tabular}{ccccc}
\hline \hline Variable & Coefficient & Marginal Effects & Coefficient & Marginal Effects \\
\hline \hline Constant & $-0.883048^{* * *}$ & - & $-1.046085^{* * *}$ & - \\
Gender & $(0.011618)$ & - & $(0.012464)$ & - \\
& $0.010768^{* * *}$ & $0.002922^{* * *}$ & $0.013359^{* * *}$ & $0.003584^{* * *}$ \\
Age & $(0.002562)$ & $(0.000694)$ & $(0.002576)$ & $(0.000690)$ \\
& $-0.003012^{* * *}$ & $-0.000818^{* * *}$ & -0.000124 & -0.000033 \\
Age Squared & $(0.000495)$ & $(0.000134)$ & $(0.000498)$ & $(0.000134)$ \\
& $0.000050^{* * *}$ & $0.000014^{* * *}$ & $0.000022^{* * *}$ & $0.000006^{* * *}$ \\
Education2dg & $(0.000005)$ & $(0.000001)$ & $(0.000005)$ & $(0.000001)$ \\
& $0.023264^{* * *}$ & $0.006316^{* * *}$ & $0.047493^{* * *}$ & $0.012741^{* * *}$ \\
Education3inc & $(0.002758)$ & $(0.000748)$ & $(0.002779)$ & $(0.000744)$ \\
& $0.012862^{* * *}$ & $0.003513^{*}$ & $0.056926^{* * *}$ & $0.015642^{* * *}$ \\
Education3dg & $(0.007534)$ & $(0.002068)$ & $(0.007586)$ & $(0.002130)$ \\
& $0.018757^{* * *}$ & $0.005131^{* * *}$ & $0.062908^{* * *}$ & $0.017289^{* * *}$ \\
Income & $(0.005252)$ & $(0.001447)$ & $(0.005303)$ & $(0.001489)$ \\
& $0.024029^{* * *}$ & $0.006528^{* * *}$ & $0.035952^{* * *}$ & $0.009660^{* * *}$ \\
D2007 & $(0.001362)$ & $(0.000370)$ & $(0.001370)$ & $(0.000368)$ \\
& -0.004785 & -0.001299 & $-0.006989^{* *}$ & $-0.001876^{* *}$ \\
D2008 & $(0.003302)$ & $(0.000896)$ & $(0.003326)$ & $(0.000891)$ \\
& $-0.178116^{* * *}$ & $-0.046706^{* * *}$ & $-0.184349^{* * *}$ & $-0.047770^{* * *}$ \\
D2009 & $(0.003426)$ & $(0.000864)$ & $(0.003449)$ & $(0.000859)$ \\
& $0.196904^{* * *}$ & $0.056301^{* * *}$ & $0.175427^{* * *}$ & $0.049332^{* * *}$ \\
Down Payment & $(0.003501)$ & $(0.001048)$ & $(0.003539)$ & $(0.001038)$ \\
& - & - & $0.009328^{* * *}$ & $0.002502^{* * *}$ \\
Interest & - & - & $(0.003194)$ & $(0.000855)$ \\
Obs Number & $1,426,688$ & - & $0.067764^{* * *}$ & $0.018208^{* * *}$ \\
Monthly Payments & - & - & $(0.000663)$ & $(0.000177)$ \\
& - & $-0.008842^{* * *}$ & $-0.002376^{* * *}$ \\
\hline \hline Pseudo R2 & - & $0.000310)$ & $(0.000083)$ \\
\hline \hline
\end{tabular}


Table 1.7: Down Payment and Interest Rate

The occurrence of down payment with and without interest rate, and its proportions, in each year. DP means the purchases with a down payment; DPNoInt means a down payment and zero interest rate; DPInt means a down payment and a positive interest rate; NDP means there was no down payment; NDPNoInt means a purchase without down payment and with zero interest rate; NDPInt means a purchase without down payment and with positive interest rate; and Total means all purchases.

\begin{tabular}{|c|c|c|c|c|}
\hline Variable & 2006 & 2007 & 2008 & 2009 \\
\hline Total & 444,790 & 477,367 & 466,932 & 319,370 \\
\hline Down Payment & 333,507 & 346,463 & 321,372 & 209,033 \\
\hline$\frac{D P}{\text { Total }}$ & $74.98 \%$ & $72.58 \%$ & $68.83 \%$ & $65.45 \%$ \\
\hline DP No Interest & 258,764 & 235,328 & 225,517 & 156,765 \\
\hline$\frac{D P N o I n t}{D P}$ & $77.59 \%$ & $67.92 \%$ & $70.17 \%$ & $75.00 \%$ \\
\hline DP Interest & 74,743 & 111,135 & 95,855 & 52,268 \\
\hline$\frac{D P I n t}{D P}$ & $22.41 \%$ & $32.08 \%$ & $29.83 \%$ & $25.00 \%$ \\
\hline No Down Payment & 111,283 & 130,904 & 145,560 & 110,337 \\
\hline$\frac{N D P}{\text { Total }}$ & $25.02 \%$ & $27.42 \%$ & $31.17 \%$ & $34.55 \%$ \\
\hline NDP No Interest & 12,041 & 11,599 & 24,966 & 19,417 \\
\hline$\frac{N D P N o I n t}{N D P}$ & $10.82 \%$ & $8.86 \%$ & $17.15 \%$ & $17.60 \%$ \\
\hline NDP Interest & 99,242 & 119,305 & 120,594 & 90,920 \\
\hline$\frac{N D P I n t}{N D P}$ & $89.18 \%$ & $91.14 \%$ & $82.85 \%$ & $82.40 \%$ \\
\hline
\end{tabular}


Table 1.8: Proportions of Number of Monthly Payments for Each YEAR

Proportion of the occurrence of monthly payments, in each year, in percentage.

\begin{tabular}{cccccc}
\hline \hline Monthly Payments & 2006 & 2007 & 2008 & 2009 & Total \\
\hline \hline 1 & 3.6 & 3.0 & 2.6 & 2.1 & 2.9 \\
2 & 1.5 & 1.6 & 2.7 & 3.9 & 2.3 \\
3 & 2.9 & 2.6 & 3.0 & 3.2 & 2.9 \\
4 & 1.9 & 2.1 & 2.2 & 2.7 & 2.2 \\
5 & 3.8 & 3.1 & 3.3 & 12.4 & 5.1 \\
6 & 1.6 & 2.4 & 2.9 & 3.7 & 2.6 \\
7 & 0.8 & 0.5 & 0.6 & 0.5 & 0.6 \\
8 & 3.1 & 1.8 & 1.7 & 1.4 & 2.0 \\
9 & 48.0 & 33.1 & 36.0 & 30.3 & 37.3 \\
10 & 4.8 & 3.3 & 3.4 & 8.0 & 4.6 \\
11 & 9.9 & 13.4 & 12.2 & 19.0 & 13.2 \\
12 & 8.2 & 20.8 & 21.6 & 7.4 & 15.2 \\
13 & 0.2 & 0.2 & - & 0.3 & 0.2 \\
14 & 0.3 & 0.1 & - & 0.1 & 0.1 \\
15 & 1.5 & 0.5 & 0.2 & 0.3 & 0.6 \\
16 & 0.5 & 0.2 & 0.1 & - & 0.2 \\
17 & 0.1 & 0.1 & 0.2 & 1.7 & 0.4 \\
18 & 0.4 & 0.2 & 1.6 & 2.2 & 1.0 \\
19 & 0.1 & - & - & - & - \\
20 & 6.7 & 2.9 & 1.4 & 0.2 & 3.0 \\
21 & - & - & - & - & - \\
22 & - & - & - & - & - \\
23 & - & - & - & - & - \\
24 & - & 8.0 & 4.0 & 0.7 & 3.5 \\
25 & - & - & 0.1 & - & - \\
\hline \hline
\end{tabular}


Table 1.9: Proportion of the Number of Monthly Payments with Zero Interest Rate, Per Year

Proportion os the occurrence of monthly payments, in each year, when there is zero interest rate, in percentage.

\begin{tabular}{cccccc}
\hline \hline Monthly Payments & 2006 & 2007 & 2008 & 2009 & TOTAL \\
\hline \hline 1 & 5.7 & 5.4 & 4.2 & 3.6 & 4.8 \\
2 & 0.5 & 1.2 & 3.0 & 5.7 & 2.3 \\
3 & 0.6 & 1.2 & 1.2 & 2.1 & 1.2 \\
4 & 0.7 & 1.8 & 1.5 & 2.3 & 1.5 \\
5 & 1.0 & 1.6 & 1.7 & 18.5 & 4.6 \\
6 & 0.4 & 0.8 & 0.9 & 0.5 & 0.7 \\
7 & 0.3 & 0.4 & 0.5 & 0.2 & 0.4 \\
8 & 0.3 & 0.4 & 0.4 & 0.2 & 0.3 \\
9 & 76.6 & 62.3 & 65.0 & 52.9 & 65.4 \\
10 & 1.5 & 1.7 & 3.0 & 6.6 & 2.9 \\
11 & 11.3 & 23.2 & 15.5 & 7,4 & 14.8 \\
12 & 1.1 & - & 3.1 & - & 1.2 \\
\hline \hline
\end{tabular}

Table 1.10: Descriptive Variables - Restricted Data Base With the Payment Plan Variables, Private Label Card

Description of the variables. Purchases made with the private label card, by the titular, from January 2006 to December 2009.

\begin{tabular}{cccc}
\hline \hline Variable & Explanation & Mean & Standard Error \\
\hline \hline Discount Occurrence & proportion of discounts & 0.1925 & - \\
\hline Gender & proportion of females & 0.6257 & - \\
Age & in years & 42.5887 & 14.0389 \\
Education1dg & proportion 1 $1^{\text {st }}$ degree & 0.3558 & - \\
Education2dg & proportion 2 ${ }^{\text {nd }}$ degree & 0.5386 & - \\
Education3inc & pp.3 $3^{\text {rd }}$ degree incomplete & 0.0303 & - \\
Education3dg & proportion $3^{\text {rd degree }}$ & 0.0754 & - \\
Income & in 1,000 Reais & 1.1150 & 0.9871 \\
\hline Down Payment & proportion of occurrence & 0.7085 & - \\
Interest & per month & 2.0270 & 2.3519 \\
Positive Interest & proportion of positive interest & 0.4472 & - \\
Interest & per month, when positive & 4.5325 & 1.0062 \\
Monthly Payments & number & 9.8323 & 4.4687 \\
\hline \hline
\end{tabular}


Table 1.11: Descriptive Variables - Single Product Payment Plan MODEL.

Description of the variables. Purchases of a single product, made with the private label card, by the titular, from January 2006 to December 2009

\begin{tabular}{cccc}
\hline \hline Variable & Explanation & Mean & Standard Error \\
\hline \hline Discount Occurrence & proportion of discounts & 0.1931 & - \\
\hline Gender & proportion of females & 0.6260 & - \\
Age & in years & 42.5963 & 14.1149 \\
Education1dg & proportion $1^{\text {st }}$ degree & 0.3611 & - \\
Education2dg & proportion $2^{\text {nd }}$ degree & 0.5381 & - \\
Education3inc & pp.3 $3^{\text {rd }}$ degree incomplete & 0.0297 & - \\
Education3dg & proportion 3 $3^{\text {rd degree }}$ & 0.0711 & - \\
Income & in 1,000 Reais & 1.0810 & 0.9366 \\
\hline Down Payment & proportion of occurrence & 0.7018 & - \\
Interest & per month & 2.08 & 2.3520 \\
Positive Interest & proportion of positive interest & 0.459 & - \\
Interest & per month, when positive & 4.52 & 0.9975 \\
Monthly Payments & number & 9.7 & 4.4472 \\
\hline \hline
\end{tabular}




\section{Table 1.12: Probit Regression Result - Kitchen Appliances And} SPECIFIC Product

Results of the regression of the occurrence of discounts, when the product is a kitchen appliance and when a specific product is bought, on the clients' characteristics and the payment plan variables. Coefficients and average marginal effects. Gender (1, when female), age (in years), age squared, education (dummy variables for $2^{\text {nd }}$ degree, $3^{\text {rd }}$ degree incomplete and $3^{\text {rd }}$ degree), income (in 1,000 Reais), yearly dummies and payment plan variables (down payment dummy, interest rate and number of monthly payments). Robust standard errors in parentheses. Significance: $* * * \mathrm{p}<0.01$; $* *$ $\mathrm{p}<0.05$ and ${ }^{*} \mathrm{p}<0.1$.

\begin{tabular}{|c|c|c|c|c|}
\hline \multirow{2}{*}{$\begin{array}{c}\text { Restriction } \\
\text { Variable }\end{array}$} & \multicolumn{2}{|c|}{ Kitchen Appliances } & \multicolumn{2}{|c|}{ Specific Product } \\
\hline & Coefficient & Marginal Effects & Coefficient & Marginal Effects \\
\hline \multirow[t]{2}{*}{ Constant } & "-0.787123 & - & $\overline{-0.918202^{* * *}}$ & - \\
\hline & $(0.021749)$ & - & $(0.053269)$ & - \\
\hline \multirow[t]{2}{*}{ Gender } & $-0.005697^{* * *}$ & -0.001698 & $0.020456^{*}$ & $0.005474^{*}$ \\
\hline & $(0.004589)$ & $(0.001369)$ & $(0.010612)$ & $(0.002833)$ \\
\hline \multirow[t]{2}{*}{ Age } & 0.002560 & $0.000763^{* * *}$ & -0.000547 & -0.000147 \\
\hline & $(0.000850)$ & $(0.000253)$ & $(0.002032)$ & $(0.000545)$ \\
\hline \multirow[t]{2}{*}{ Age Squared } & $-0.000002^{* * *}$ & -0.000001 & 0.000031 & 0.000008 \\
\hline & $(0.000009)$ & $(0.000003)$ & $(0.000021)$ & $(0.000006)$ \\
\hline \multirow[t]{2}{*}{ Education2dg } & $0.042363^{* * *}$ & $0.012602^{* * *}$ & $0.066457^{* * *}$ & $0.017787^{* * *}$ \\
\hline & $(0.004863)$ & $(0.001444)$ & $(0.011412)$ & $(0.003047)$ \\
\hline \multirow[t]{2}{*}{ Education3inc } & $0.036958 * * *$ & $0.011147^{* * *}$ & $0.085643^{* * *}$ & $0.023748^{* * *}$ \\
\hline & $(0.013175)$ & $(0.004022)$ & $(0.032046)$ & $(0.009174)$ \\
\hline \multirow[t]{2}{*}{ Education3dg } & $0.043935^{* * *}$ & $0.013263^{* * *}$ & $0.077215^{* *}$ & $0.021282^{* *}$ \\
\hline & $(0.008952)$ & $(0.002738)$ & $(0.021438)$ & $(0.006066)$ \\
\hline \multirow[t]{2}{*}{ Income } & $0.027546^{* * *}$ & $0.008206^{* * *}$ & $0.025476^{* * *}$ & $0.006833^{* * *}$ \\
\hline & $(0.002323)$ & $(0.000692)$ & $(0.005905)$ & $(0.001584)$ \\
\hline \multirow[t]{2}{*}{ D2007 } & $-0.081140^{* * *}$ & $-0.023843^{* * *}$ & $-0.294732^{* * *}$ & $-0.074947^{* * *}$ \\
\hline & $(0.005904)$ & $(0.001710)$ & $(0.014848)$ & $(0.003559)$ \\
\hline \multirow[t]{2}{*}{ D2008 } & $-0.333121^{* * *}$ & $-0.094250 * * *$ & $-0.205018^{* * *}$ & $-0.053347^{* * *}$ \\
\hline & $(0.006058)$ & $(0.001609)$ & $(0.014416)$ & $(0.003629)$ \\
\hline \multirow[t]{2}{*}{ D2009 } & $-0.098170^{* * *}$ & $-0.028609^{* * *}$ & $0.076365^{* * *}$ & $0.020900^{* * *}$ \\
\hline & $(0.006372)$ & $(0.001814)$ & $(0.015417)$ & $(0.004303)$ \\
\hline \multirow[t]{2}{*}{ Down Payment } & $0.017211^{* * *}$ & $0.005112^{* * *}$ & $0.078741^{* * *}$ & $0.020528 * * *$ \\
\hline & $(0.005586)$ & $(0.001654)$ & $(0.0014399)$ & $(0.003691)$ \\
\hline \multirow[t]{2}{*}{ Interest } & $0.068456^{* * *}$ & $0.020392^{* * *}$ & $0.067764^{* * *}$ & $0.021118^{* * *}$ \\
\hline & $(0.001161)$ & $(0.000343)$ & $(0.002864)$ & $(0.000763)$ \\
\hline \multirow[t]{2}{*}{ Monthly Payments } & $-0.013789^{* * *}$ & $-0.004108^{* * *}$ & $-0.012518^{* * *}$ & $-0.003357 * * *$ \\
\hline & $(0.000543)$ & $(0.000162)$ & $(0.001355)$ & $(0.000363)$ \\
\hline Pseudo R2 & 0.0182 & & 0.0216 & \\
\hline Obs Number & 437,856 & & 85,290 & \\
\hline
\end{tabular}


Table 1.13: Probit Regression Result - High And Low Price ProDUCTS

Results of the regression of the occurrence of discounts, when the price is above 1.000,00 Reais and when it is below or equal to 1.000,00 Reais, on the clients' characteristics and the payment plan variables. Coefficients and average marginal effects. Gender (1, when female), age (in years), age squared, education (dummy variables for $2^{\text {nd }}$ degree, $3^{\text {rd }}$ degree incomplete and $3^{\text {rd }}$ degree), income (in 1,000 Reais), yearly dummies and payment plan variables (down payment dummy, interest rate and number of monthly payments). Robust standard errors in parentheses. Significance: ${ }^{* * *} \mathrm{p}<0.01$; ** $\mathrm{p}<0.05$ and $* \mathrm{p}<0.1$

\begin{tabular}{|c|c|c|c|c|}
\hline \multirow{2}{*}{$\begin{array}{c}\text { Restriction } \\
\text { Variable }\end{array}$} & \multicolumn{2}{|c|}{ High Price } & \multicolumn{2}{|c|}{ Low Price } \\
\hline & Coefficient & Marginal Effects & Coefficient & Marginal Effects \\
\hline \multirow[t]{2}{*}{ Constant } & $\overline{-0.600896^{* * *}}$ & - & $-0.990705^{* * *}$ & - \\
\hline & $(0.028774)$ & - & $(0.014059)$ & - \\
\hline \multirow[t]{2}{*}{ Gender } & $-0.010715^{*}$ & $-0.003394^{*}$ & $0.019059^{* * *}$ & $0.004824^{* * *}$ \\
\hline & $(0.005558)$ & $(0.001762)$ & $(0.002933)$ & $(0.000741)$ \\
\hline \multirow[t]{2}{*}{ Age } & -0.000211 & -0.000067 & $-0.002623^{* * *}$ & $-0.000665^{* * *}$ \\
\hline & $(0.001119)$ & $(0.000354)$ & $(0.000560)$ & $(0.000142)$ \\
\hline \multirow[t]{2}{*}{ Age Squared } & 0.000019 & 0.000006 & $0.000043^{* * *}$ & $0.000011^{* * *}$ \\
\hline & $(0.000012)$ & $(0.000004)$ & $(0.000006)$ & $(0.000001)$ \\
\hline \multirow[t]{2}{*}{ Education2dg } & $0.046617^{* * *}$ & $0.014734^{* * *}$ & $0.037298^{* * *}$ & $0.009450^{* * *}$ \\
\hline & $(0.006166)$ & $(0.001945)$ & $(0.003137)$ & $(0.000794)$ \\
\hline \multirow[t]{2}{*}{ Education3inc } & $0.070135^{* * *}$ & $0.022649 * * *$ & $0.031777^{* * *}$ & $0.008170^{* * *}$ \\
\hline & $(0.015764)$ & $(0.005189)$ & $(0.008742)$ & $(0.002277)$ \\
\hline \multirow[t]{2}{*}{ Education3dg } & $0.084225^{* * *}$ & $0.027215^{* * *}$ & $0.025886^{* * *}$ & $0.006633^{* * *}$ \\
\hline & $(0.010178)$ & $(0.003353)$ & $(0.006302)$ & $(0.001631)$ \\
\hline \multirow[t]{2}{*}{ Income } & $0.017306^{* * *}$ & $0.005478^{* * *}$ & $0.025886^{* * *}$ & $0.005246^{* * *}$ \\
\hline & $(0.002496)$ & $(0.000790)$ & $(0.001688)$ & $(0.000428)$ \\
\hline \multirow[t]{2}{*}{ D2007 } & $-0.226539^{* * *}$ & $-0.069602^{* * *}$ & $0.043740^{* * *}$ & $0.011194^{* * *}$ \\
\hline & $(0.007463)$ & $(0.002213)$ & $(0.003739)$ & $(0.000965)$ \\
\hline \multirow[t]{2}{*}{ D2008 } & $-0.225128^{* * *}$ & $-0.068973^{* * *}$ & $-0.192681^{* * *}$ & $-0.046921^{* * *}$ \\
\hline & $(0.007604)$ & $(0.002241)$ & $(0.003926)$ & $(0.000914)$ \\
\hline \multirow[t]{2}{*}{ D2009 } & $-0.065569^{* * *}$ & $0.021031^{* * *}$ & $0.172777^{* * *}$ & $0.045976^{* * *}$ \\
\hline & $(0.007719)$ & $(0.002507)$ & $(0.004034)$ & $(0.001122)$ \\
\hline \multirow[t]{2}{*}{ Down Payment } & $0.101094^{* * *}$ & $0.031277^{* * *}$ & $-0.031300^{* * *}$ & $-0.007981^{* * *}$ \\
\hline & $(0.007638)$ & $(0.002307)$ & $(0.003556)$ & $(0.000912)$ \\
\hline \multirow[t]{2}{*}{ Interest } & $0.090010^{* * *}$ & $0.028491^{* * *}$ & $0.075896^{* * *}$ & $0.019253^{* * *}$ \\
\hline & $(0.001529)$ & $(0.000476)$ & $(0.000754)$ & $(0.000190)$ \\
\hline \multirow[t]{2}{*}{ Monthly Payments } & $-0.022151^{* * *}$ & $-0.007012^{* * *}$ & $-0.013754^{* * *}$ & $-0.003489^{* * *}$ \\
\hline & $(0.000652)$ & $(0.000205)$ & $(0.000370)$ & $(0.000094)$ \\
\hline Pseudo R2 & 0.0225 & & 0.0243 & \\
\hline Obs Number & 270,430 & & $1,156,258$ & \\
\hline
\end{tabular}


Table 1.14: Linear Regression Result - Discount Value Results of the linear regression of the discount values, on the clients' characteristics and payment plan variables. OLS coefficients. Gender (1, when female), age (in years), age squared, education (dummy variables for $2^{\text {nd }}$ degree, $3^{\text {rd }}$ degree incomplete and $3^{\text {rd }}$ degree), income (in 1,000 Reais), yearly dummies and payment plan variables (down payment dummy, interest rate and number of monthly payments). Robust standard errors in parentheses. Significance: ${ }^{* * *} \mathrm{p}<0.01 ;{ }^{* *} \mathrm{p}<0.05$ and ${ }^{*} \mathrm{p}<0.1$.

\begin{tabular}{|c|c|c|c|}
\hline $\begin{array}{c}\text { Data Base } \\
\text { Variable }\end{array}$ & $\begin{array}{l}\text { Censored } \\
\text { Coefficients }\end{array}$ & $\begin{array}{c}\text { Total } \\
\text { Coefficients }\end{array}$ & $\begin{array}{l}\text { Truncated } \\
\text { Coefficients }\end{array}$ \\
\hline Constant & $\begin{array}{c}2.734146^{* * *} \\
(0.705202)\end{array}$ & $\begin{array}{c}-4.545843^{* * *} \\
(0.563373)\end{array}$ & $\begin{array}{c}-1.897721^{* * *} \\
(0.197564)\end{array}$ \\
\hline Gender & $\begin{array}{c}-1.132586^{* * *} \\
(0.158120)\end{array}$ & $\begin{array}{c}-0.862366^{* * *} \\
(0.119745)\end{array}$ & $\begin{array}{c}-0.092212^{* * *} \\
(0.042050)\end{array}$ \\
\hline Age & $\begin{array}{c}0.483832^{* * *} \\
(0.028394)\end{array}$ & $\begin{array}{c}0.189563^{* * *} \\
(0.022930)\end{array}$ & $\begin{array}{c}0.078070^{* * *} \\
(0.007975)\end{array}$ \\
\hline Age Squared & $\begin{array}{c}-0.003880^{* * *} \\
(0.000299)\end{array}$ & $\begin{array}{c}-0.001467^{* * *} \\
(0.000234)\end{array}$ & $\begin{array}{c}-0.000404^{* * *} \\
(0.000085)\end{array}$ \\
\hline Education2dg & $\begin{array}{c}2.825688^{* * *} \\
(0.157328)\end{array}$ & $\begin{array}{c}2.512378^{* * *} \\
(0.115581)\end{array}$ & $\begin{array}{c}0.992222^{* * *} \\
(0.042343)\end{array}$ \\
\hline Education3inc & $\begin{array}{c}5.890723^{* * *} \\
(0.489930)\end{array}$ & $\begin{array}{c}6.190759^{* * * *} \\
(0.395217)\end{array}$ & $\begin{array}{c}1.708156^{* * *} \\
(0.130647)\end{array}$ \\
\hline Education3dg & $\begin{array}{c}6.657550^{* * *} \\
(0.383532)\end{array}$ & $\begin{array}{c}6.327809^{* * *} \\
(0.332873)\end{array}$ & $\begin{array}{c}1.917462^{* * *} \\
(0.103139)\end{array}$ \\
\hline Income & $\begin{array}{c}4.910937^{* * *} \\
(0.138514)\end{array}$ & $\begin{array}{c}5.706458^{* * *} \\
(0.146429)\end{array}$ & $\begin{array}{c}1.527184^{* * *} \\
(0.035738)\end{array}$ \\
\hline D2007 & $\begin{array}{c}-1.033535^{* * *} \\
(0.174897)\end{array}$ & $\begin{array}{c}3.602566^{* * *} \\
(0.135700)\end{array}$ & $\begin{array}{c}-0.286198^{* * *} \\
(0.047566)\end{array}$ \\
\hline D2008 & $\begin{array}{c}6.274758^{* * *} \\
(0.211554)\end{array}$ & $\begin{array}{c}4.154278^{* * *} \\
(0.148828)\end{array}$ & $\begin{array}{c}-0.546266^{* * *} \\
(0.049543)\end{array}$ \\
\hline D2009 & $\begin{array}{c}10.763260^{* * *} \\
(0.199149)\end{array}$ & $\begin{array}{c}12.160830^{* * *} \\
(0.162374)\end{array}$ & $\begin{array}{c}4.617794^{* * *} \\
(0.065826)\end{array}$ \\
\hline Down Payment & $\begin{array}{c}6.884772^{* * *} \\
(0.167866)\end{array}$ & $\begin{array}{c}3.208311^{* * * *} \\
(0.138197)\end{array}$ & $\begin{array}{c}1.710116^{* * *} \\
(0.049583)\end{array}$ \\
\hline Interest & $\begin{array}{c}-3.035604^{* * *} \\
(0.040107)\end{array}$ & $\begin{array}{c}-0.706475^{* * *} \\
(0.029483)\end{array}$ & $\begin{array}{c}0.164399^{* * *} \\
(0.010585)\end{array}$ \\
\hline Monthly Payments & $\begin{array}{c}1.649586^{* * *} \\
(0.017952) \\
\end{array}$ & $\begin{array}{c}0.587261^{* * *} \\
(0.015056) \\
\end{array}$ & $\begin{array}{c}0.247244^{* * *} \\
(0.005529) \\
\end{array}$ \\
\hline $\mathrm{R} 2$ & 0.102 & 0.0144 & 0.01 \\
\hline Obs Number & 275,540 & $1,426,688$ & $1,426,688$ \\
\hline
\end{tabular}




\section{The Effects of the Payment Plan Choice and the Non Observable Characteristics on Default Probability}

This paper estimates the effect of asymmetric information on consumer loans, using data from kitchen appliance, home appliance and image equipment sales of a chain store, the payment plan chosen by the client and his observable characteristics. We decompose the effect into an adverse selection and a causal component using a technique similar to Adams et al. (2009). We find significant marginal effects and conclude that the causal effect of the payment plan choice is greater than the one caused by the adverse selection. We employ two different variables to represent the payment plan: the interest rate and the number of monthly payments. When we use the first one, we find its positive effect on default probability is more than two times the adverse selection effect. When we use the second one, its effect on default probability is positive and greater than six times the adverse selection one, when the interest rate is positive and negative and half the adverse selection effect when the interest rate is zero.

Asymmetric information case is an important issue in consumer financing. A store that allows the purchase to be divided into several monthly payments knows little about the client's intention to pay the totality of the value owned. Some important questions are if different contract menus can separate different types according to default risk and if the financing contract can affect default risk directly. A major difficulty is to identify each of the effects of adverse selection and moral hazard separately.

Chiappori \& Salanié (2000) provide a simple and general test of the presence of asymmetric information in contractual relationships in the French market for automobiles. The paper uses data on contracts and accidents on their empirical investigations and does not distinguish between adverse selection or moral hazard. They find no evidence for the presence of asymmetric information. Using again insurance data, Abbring et al. (2003) suggest that it is possible to distinguish moral hazard from selection on non observable characteristics. According to them, the form of optimal dynamic contracts differs considerably between the two cases. The contracts are taken as given and the occurrence of an accident shifts the entire incentive scheme the agent is facing. Under moral hazard, this results in a form of autocorrelation in 
the accident process. In the case of adverse selection, the contractual changes that take place during the relationship may be informative about the agent's riskiness.

Some other works manage to separate the two effects. Ausubel (1999) examines the results of randomized trials in preapproved credit card solicitations and Silva (2012) studies the market for consumer credit for auto loans, using data from one of the largest banks in Brazil. His two-stage estimation also includes data from another loan modality (personal credit). Karlan \& Zinman (2009) uses information of former clients of a South African lender and find strong evidence of moral hazard and weak evidence of hidden information problem in credit market. The randomized variations of three rates, offer, contract and future rate, allow them to separate the ex-post hidden action presence from the hidden information and ex-ante hidden action.

Adams et al. (2009) use auto sale company data (used cars) to separate the loan size effect (which they call moral hazard) from the non observable characteristic effect (adverse selection) on default probability. They work with the sub-prime market, where high interest rates (25-30\%) and high default rates (over half loans end in default) can be observed. The consumers have limited borrowing opportunities and liquidity constraints, because of their low income and poor credit histories. We also work with consumers with liquidity and credit restrictions.

In their paper, buyers choose the down payment. The bigger the down payment value, the smaller the loan size. In our case, the down payment is given. Buyers chose the number of monthly payments and the interest rate from a menu of options given by the store. For the shortest lengths, that is, the smallest number of monthly payments, there are no interest rates. From a specific number of monthly payments on, depending on the product, there are associated increasing positive interest rates. For a positive interest rate, the larger the number of monthly payments, the bigger the loan size.

A crucial aspect of the identification strategy is the choice of the exogenous variable. Adams et al. (2009) choose the price of the product as theirs. Their key assumption is that repayment behavior does not depend directly on pricing markup or the minimum down payment. But only on the payment plan choice variable, that is, in their case, the loan size. In our case, we do have a stronger exogenous variable to use as control in the first stage. Instead of prices, we use as the exogenous variable the "saldão" dummy variable, that is, a variable that is one when the month of the purchase is one of the months when one special payment plan is also available: eleven monthly payments, with zero interest rate. Those months are also when goods are on sale. The price of 
the product, the exogenous variable used by them is extremely correlated to the resale value of the car chosen and the car is the collateral of the loan. The collateral might, then, be correlated to the probability of default. Our variable, on the other hand, does not depend on the product chosen. It clearly influences the payment plan choice but the repayment behavior does not depend on it. The alternative payment plan available is decided by the firm and in the kitchen and home appliance case, there is no collateral.

It is true that the menu of payment choices depend on the products characteristics, but not on clients' contemporaneous choices or the repayment behavior of that product bought. Only the menu itself is correlated to the exogenous variable, once the products with nine monthly payments with no interest are the ones that will have eleven monthly payments with no interest as a payment plan option. Our products do not have a resale market and even if they did, the resale value depends on the products price, but not on the financing plan that was chosen for its purchase. In the kitchen and home appliance market if the client does not pay all the monthly payments she was supposed to pay, the store does not take the product back.

Section 2.1 describes the data base. Section 2.2 compares the choice of monthly payments and the clients'characteristics for "saldão" months and non "saldão" months. Section 2.3 discusses the exogenous variable used, and explains some estimation details. Section 2.4 shows the results of the two stages. Section 2.5 uses the number of monthly payments as the dependent variable of the first stage and finds a compatible result. Finally, Section 2.6 concludes.

\subsection{Data}

Our database includes data from May 2009 to May 2011, from a kitchen and home appliance store. It has purchases paid with the private label card, clients' characteristics and the payment plan chosen. All purchases have financing plans that have ended, that is, that are closed: they are fully paid or default.

The private label card is not like a regular credit card. It is a card that allows the client to divide the payment of a purchase in monthly payments. It acts like a "crediário", a very common practice in Brazil. The owner of the card has to go to the store to pay all the partial payments. The card can be used only to buy things in the stores of the same chain. Each client's card has an individual credit limit, decided by the firm, that depends on the proved income and the history of the client as a debtor of the firm. In the case of the firm we are studying, the credit limit is expressed in terms of a the maximum 
value of the monthly payments of all the purchases made in the store, and not yet paid.

Despite the fact that additional cards can be done, only the purchases of the titular are used. We only observe the characteristics of the main card holder. This solution does not eliminate the possibility of the product being bought by someone else. That is the owner of the card can use it to buy while someone else is responsible for the actual payments. The hypotheses we need here are that the person that is responsible for the payments is the one who chooses the payment plan and that the characteristics of them (the owner of the card and the one who will pay the partial payments) are similar.

The clients' characteristics considered are: gender (female equals one), age (in years), education (equals one when the client has completed elementary or primary school called $1^{\text {st }}$ degree, secondary or high school called $2^{\text {nd }}$ degree and incomplete and complete college or university called $3^{\text {rd }}$ degree) and income (in 1,000 Reais). These were collected from an application form that had to be filled out order to get the private label card. This is one of the reasons why only the purchases that use this card as the payment plan are used. Regular credit card purchases and purchases in cash (in currency or by cheques) will not be considered.

We also use information on the payment plan details. We observe if there was a down payment, the payment plan (how many partial payments) and the interest rate paid. For each product offered there is a menu of financing plans available. Menus are the same for every store of the chain. They are based on the historic default among consumers of each product. A product can be sold with a required down payment or not. The menus are the same for all buyers, i.e., there is no discrimination at this point.

Since the payment plan menu varies from one product to another, we focus the analysis on purchases of one single product. Doing this, the fact that one product's payment option could restrict others is avoided. The payment plan chosen is, then, the one the client thinks is the best, given those that are available for that product and that satisfied the restriction she has because of her credit limit.

The limit is determined as the maximum value a monthly payment can reach. This act as two different forces. First, some buyers have to choose longer payment plans in order to allow the month payment value to be smaller than the limit. Second, some buyers cannot buy products more expensive than a certain price because even splitting the payment in the larger possible number of monthly payments, the monthly payment value is bigger than the maximum permitted by the buyer's card. That is why it is so important to include the 
credit limit.

Since we do not observe the credit limits themselves, we add as regressors the debt of the client with the chain store over income and the payment done by the client, that is, the total amount the client has paid in the past to repay former debts. These variables determine the credit limit of each client.

We also use information about the month of the purchase. This information is important because the exogenous variable used in the first stage is a dummy variable that is one when the month of the purchase is one of the "saldão" months (January, April or September), that is, when one special payment plan is also available.

Table 2.2 shows some descriptive variables. It shows that there are more female than male clients, $67 \%$. The average age is 44 years old. Clients who went to the university (considering those still in it) are only around 10 per cent. The majority has finished not only the fundamental but also medium level ( $55 \%$ has the second degree). Average income is 1,111.13 Reais, per month. More than one third of the purchases occurred during the sales months and more than half of the purchases include a down payment. $51 \%$ of the purchases include positive interest rates and the average rate is $4.48 \%$ per month. The average number of monthly payments is 6, the average debt is high $(83 \%$ of their income) and 330.34 Reais is the average volume of older payments already done to the store.

\subsection{Choice of The Exogenous Variable: "Saldão" and Non "Saldão" Months}

To work the way we want, we expect the "saldão" dummy to affect the choice of the payment plan, but not to affect the default probability through other way than the payment plan choice itself. In order to reinforce the argument that the exogenous variable we use is a good one, we show some tables to compare the payment plan choice and the clients' characteristics for "saldão" months and non "saldão" months.

Tables 2.3, 2.4, and 2.5 show the occurrences of monthly payments for all months, for "saldão" months and for non "saldão" months, respectively. The three of them show the occurrence of monthly payments for all purchases and the fraction with zero interest.

When considering all months (Table 2.3), the greatest occurrence is five monthly payments. $20 \%$ of the choices are of financial plans with this number of payments. $75.15 \%$ of them are with zero interest rate and $24.85 \%$ with a positive one. The second most popular number of payments is nine $(15.36 \%$ of the choices). In this case the financial plans chosen are in their great majority 
without interest: $94.55 \%$ of them.

Restricting to the "saldão" months (Table 2.4), nine monthly payments are more common than five, $28.51 \%$ and $23.37 \%$, respectively. The proportion of both of them combined with zero interest rate increased: $98.61 \%$ for nine and $86.06 \%$ for five. The most interesting choice to be noted is that $94.40 \%$ of the chosen financial plans with eleven monthly payments are combined with zero interest rate. This reflects the payment plan that is available when it is one of "saldão" months, that is not for the other nine months. During "saldão" months, the payment plans with positive rates are not very popular. Only $32.55 \%$ of choices are with positive interest rates. When it is not a "saldão" month this proportion increases to $60.54 \%$.

Table 2.5 completes the analysis. This table shows the proportion of sales when it is not a "saldão" month. The most popular monthly payment number is five: $19.48 \%$ of the sales of this period. $68.63 \%$ of them are with zero interest rate. Nine monthly payments are not chosen as frequent as when it is "saldão" time (it is the forth most common option, with $8.79 \%$ of purchases), but it is interesting to notice that $87.99 \%$ of the purchases when nine monthly payments will be paid is with zero interest rate. Nine is the greatest number available with no interest when it is not a "saldão" month.

Clients characteristics do not change significantly. As showed in Table 2.6, the proportions of men and women that buy during "saldão" months and during the other nine months are the same: $33.5 \%$ of men and $66.5 \%$ of women. The difference of education is also very small. The proportion of clients with only the primary school increases from $33.5 \%$ to $34.0 \%$, while the proportion of clients with a university diploma decreases from $7.8 \%$ to $7.1 \%$. The other two possibilities remain the same. The average income decreases from $\mathrm{R} \$ 1.13$ thousand to $\mathrm{R} \$ 1.10$ thousand, as showed in the table. On the other hand, the proportion of the interest rate chosen, zero or positive, changes a lot. As could be expected, the proportion of purchases with zero interest rate increases a lot when it is a "saldão" month. When it is possible to buy dividing the payment into ten or eleven monthly payments without paying any interest, the proportion of clients that chooses each type is almost the opposite. When it is not a "saldão" month $60.5 \%$ os the clients pay a positive interest rate and $39.5 \%$ choose to pay no interest. When it is a "saldão" month, only $32.5 \%$ pay a positive interest rate, while $67.5 \%$ of the clients decides for a financial plan when no interest rates are paid. 


\subsection{Estimation: Understanding the Residual}

Default probability might increase for three reasons. First, because of some client's characteristics that can be observed by the firm. Second, it might increase with other characteristics that are not observed by the firm. Finally, it might increase because of the payment plan chosen. We want to isolate the effect of characteristics that are not observed from the effect of the contract choice, that is, the interest rate choice. We use the simplest specification: a probit model for default probability. Only purchases that achieved an end are included, that is, those that have been fully paid or those with default. The purchases that are already being paid were excluded.

The estimation is done in two stages. In the first stage we estimate the following equation.

$$
\operatorname{pag}_{i j t}=\alpha_{0}+H_{i}^{\prime} \alpha_{1}+D_{t}^{\prime} \alpha_{2}+X_{j t}^{\prime} \alpha_{3}+s j t \alpha_{4}+\mu_{i j t}
$$

, where $p a g_{i j t}$ is the payment plan chosen by client $i$ when she buys the product $j$ at time $t . H_{i}$ is the vector of characteristics of client $i$ (do not change). It includes gender (1, when female), age (in years), age squared, education (dummy variables for $2^{\text {nd }}$ degree, $3^{\text {rd }}$ degree incomplete and $3^{\text {rd }}$ degree) and income (in 1,000 Reais). $D_{t}$ is the vector of yearly dummy variables. $X_{i j t}$ is the vector of financial characteristics of the client. It includes debt with the store per income and the value of all payments already done from past contracts with the store. $s_{i j t}$ is the exogenous variable for the product $j$ at time $t . \mu_{i j t}$ is the error.

From this first stage we get $\hat{\mu}_{i j t}$, which is the estimated residual.

$$
\hat{\mu}_{i j t}=p a g_{i j t}-\hat{\alpha_{0}}-H_{i}^{\prime} \hat{\alpha_{1}}-D_{t}^{\prime} \hat{\alpha_{2}}-X_{j t}^{\prime} \hat{\alpha_{3}}-s_{j t} \hat{\alpha_{4}}
$$

, where all the hats mean estimated values.

From the first stage we calculate the variable we call Non Observable. We know that there are other non observable characteristics that can influence the payment plan choice that are not included as independent variables. They are responsible for adverse selection, that can occur when there is asymmetric information. The residual of the first stage is everything that influences the interest rate choice besides the observable characteristics and the credit limit. In other words, it is the characteristics of the client that can not be observed by the firm, plus an error. These characteristics affect both the payment plan choice and the probability of default.

In the second stage we include the clients' characteristics, dummies of years, the payment plan chosen and $\hat{\mu}_{i j t}$ as independent variables. 
$\operatorname{Prob}\left(\operatorname{def}_{i j t}=1 \mid H, D, X, p a g, \hat{\mu}\right)=\Phi\left(\beta_{0}+H_{i}^{\prime} \beta_{1}+D_{t}^{\prime} \beta_{2}+X_{j t}^{\prime} \beta_{3}+p a g_{i j t} \beta_{4}+\hat{\mu}_{i j t} \beta_{5}\right)$

, where $\Phi$ is the cumulative normal distribution. $d e f_{i j t}$ is the dummy variable that indicates the occurrence of default on the financial contract made for client $i$ when she bought the product $j$ at time $t . H_{i}$ is the vector of characteristics of client $i$ (do not change), as in the first stage. $D_{t}$ is the vector of yearly dummy variables. $X_{i j t}$ is the vector of financial characteristics of the client. It includes debt with the store per income and the value of all payments already done from past contracts with the store. pag $_{i j t}$ is the the payment plan variable chosen by client $i$ for the product $j$ at time $t$ (the dependent variable of the first stage). $\hat{\mu}_{i j t}$ is the estimated residual of the first stage, as explained above.

To decide which variable is the best to represent the payment plan chosen there are some important particularities to consider. First, the existence of a down payment is not a completely free choice, that is, some products are sold only if a down payment is paid. Then it is not an option. Second, when we look to the interest rate case, the client necessarily have a worst contract, in other words, she pays a bigger total price. The length of the contract is longer but the total value paid must be bigger too. Finally, the number of monthly payments is not monotonic variable. For purchases with zero interest the increase of the number of monthly payments does not means an increase of the total value paid, on the contrary, the client pays the same (or even less, if we consider present values).

Because of these issues we selected the interest rate as the payment plan choice variable. We then do an exercise using the number of monthly payments, as a robustness test.

\subsection{Results}

Using the interest rate as the dependent variable of the first stage we have the results shown on Table 2.7. All the coefficients are highly significant. The better the education, the lower the interest rate chosen. Female clients choose contracts with higher interest rate. Income and interest rate have a negative correlation. The ratio client's debt over income increases the interest rate chosen and the payment done before decreases it. "Saldão" has a negative effect on the interest rate.

For gender, age and payment done before we did not have expectations about the sign of this first stage. The same for the years dummy, as their coefficients do not have a significate. For education and income we expected a negative sign. We expected a positive sign for debt over income. In the 
education case, as they represent the capacity of being informed, it would be reasonable to have well educated clients choosing better contracts. A higher income allowed the client to choose a bigger monthly payment value, which means a smaller interest rate. The debt over income ratio means the client has already a debt with the firm and would probably need a longer length, which means a higher interest rate.

We know the payment plan is a choice limited by the menu of options and the credit limit and is driven by the clients' characteristics. The credit limit is included in the estimation explicitly when we included the debt over income and the payment done before, since they are the variables that determine this limit. We also have some demographic characteristics (gender, age, education and income). But we know that there are other non observable characteristics that can influence the payment plan choice that are not included as independent variables. They are responsible for adverse selection, that can occur when there is asymmetric information, which is the case. They are the residual of this first stage and will be included as an independent variable in the second stage.

Table 2.8 shows the results of the second stage of the estimation. All the marginal effects are significant. Our main result is that the higher the interest rate chosen, the higher the probability of default. And the non observable characteristics of the client also increases this probability. The presence of a positive and significant marginal effect of the non observable characteristics means that the different menus do not fully eliminate the adverse selection. But this effect on default probability is less than half of the effect of the interest rate chosen.

Table 2.8 also shows that having a secondary school or a university degree decreases the probability of default. Being a woman also decreases this probability. The higher the income, the lower the probability. The ratio debt over income increases while the payment done decreases the probability of default. Except for gender, which we did not have expectations about the sign we would find, all others are as we expected.

\subsection{Different Choice Variable}

Since payment plan menus are fixed, the choice of a higher interest rate is also the choice of a larger number of monthly payments. Using the number of monthly payments as the dependent variable of the first stage we have the results on Table 2.9. All the coefficients are highly significant. The better the education, the lower the interest rate chosen. Female clients choose contracts with smaller number of monthly payments. Income and number of monthly 
payments have a negative correlation. The ratio client's debt over income increases the number of monthly payments chosen and the payment done before decreases it. "Saldão" has a positive effect on the variable.

Table $2.10^{1}$ shows the results of the second stage of the estimation when the choice variable considered is the number of monthly payments. We can see that there is a negative relation between the probability of default and the number of partial payments, what contradicts, at a first sight, the interest rate result. The non observable characteristics of the client and the probability of default still positively related. And the signs of the observable characteristics are equal to the ones from the regression of the interest rate as the payment plan choice variable.

To resolve the apparent contradiction of the results we must remember that when the interest rate chosen is zero, a larger number of monthly payments does not imply more indebtedness. The client faces smaller monthly payment values, longer length and the same total value to pay. We estimate again the second stage considering this break. We run the second stage separating the purchases with zero interest rates from the purchases with positive ones, allowing different effects on default probability for the two different cases.

Table 2.11 shows the results of the second stage of the estimation when the choice variable considered is the number of monthly payments and we included a dummy variable for the interest rate. The most interesting result is that the number of monthly payments average marginal effect is negative, when the interest rate is zero and positive when the interest rate is positive. This means that as the number of monthly payments increases, the probability of default decreases when this increase represents a better contract and the probability increases when this increase represents a worse contract. The effect on default probability of the number of monthly payments chosen is greater than six times the adverse selection effect, when the interest rate is positive and half the same effect when it is zero.

All the other average marginal effects (except for the age squared which is not significant) have the same sign for zero and positive coefficients. They are negative for gender, education, income and payment done, and positive for debt over income and non observable characteristics.

\footnotetext{
${ }^{1}$ Tables $2.12,2.13,2.14$ and 2.15 show the second stages of the main regressions (the first stages are the same) when we omit one of the independent variables. First we omit the Non Observable and then the payment plan choice variable.
} 


\subsection{Conclusion}

This paper estimated the effect of asymmetric information on consumer loans, using data from kitchen appliance, home appliance and image equipment sales of a chain store, the payment plan chosen by the client and his observable characteristics. We could decompose the effect into an adverse selection (the effect from characteristics that are not observed) and a causal component (the effect of the contract chosen) using a technique similar to Adams et al. (2009). We used a simple specification: a probit model in default. The coefficients and marginal effects are significant and have the signs we expected. We also concluded that the effect of the payment plan choice is greater than the one caused by the adverse selection.

The estimation done was a two-stage estimation. The first stage was a linear regression of the payment plan variable chosen on the clients' characteristics (gender, age, education and income), dummies of years, variables of the credit limit (debt over income, payments done before and income) and an exogenous variable. From this first stage we get $\hat{\mu}_{i j t} \cdot \hat{\mu}_{i j t}$, the estimated residual, is everything that influences the interest rate choice besides the observable characteristics and the credit limit. In other words, it is the characteristics of the client that can not be observed by the firm, plus an error. These characteristics affect both the payment plan choice and the probability of default. In the second stage we included the clients' characteristics, dummies of years, the payment plan chosen and $\hat{\mu}_{i j t}$ as independent variables.

We used as exogenous variable a dummy variable that is one when the month of the purchase is one of the "saldão" months (January, April or September), that is, when one special payment plan is also available: eleven monthly payments, with zero interest rate. The alternative payment plan available is decided by the firm. The menu of payment choices do not depend on clients' contemporaneous choices or on the repayment behavior of that product bought. Only the menu itself is correlated to the exogenous variable, once the products with nine monthly payments with no interest are the ones that will have eleven monthly payments with no interest as a payment plan option. Our products do not have a resale market and the financing plans do not include a collateral.

When we looked to the interest rate as the payment plan choice variable we get our main result: the higher the interest rate chosen, the higher the probability of default, and the non observable characteristics of the client also increases this probability. The presence of a positive and significant marginal effect of the non observable characteristics means that the different menus do not fully eliminate the adverse selection. But this effect on default probability 
was less than half of the effect of the interest rate chosen.

We then did an exercise using the number of monthly payments as the payment plan choice, our analysis took into account the fact that when the interest rate chosen is zero, the number of monthly payments has a different effect. The larger it is, the better is the contract chosen. The client faces smaller monthly payment values, longer length and the same total value to pay. We estimate then the second stage considering this break. For zero and positive interest rate we can have different effects on default probability. We included the interaction of the variables with the interest rate dummies.

Separating the effects for the number of monthly payment, with positive and zero interest, we found what we expected. The number of monthly payments marginal effect is negative, when the interest rate is zero and positive when the interest rate is positive. This means that as the number of monthly payment increases, the probability of default decreases when this increase represents a better contract and the probability increases when this increase represents a worse contract. The effect on default probability of the number of monthly payments chosen is greater than six times the adverse selection effect, when the interest rate is positive and half the same effect when it is zero. All the other marginal effects (except for the age squared which is not significant) have the same sign for zero and positive coefficients. They are negative for gender, education, income and payment done, and positive for debt over income and non observable characteristics. 
Table 2.1: Payment Plan Example

Example of a refrigerator payment plan menu

\begin{tabular}{cccc}
\hline \hline Down Payment & Payment Number & Monthly Payment & Total Value \\
\hline \hline 1 & 0 & $2,399.00$ & $2,999.00$ \\
1 & 1 & $1,289.25$ & $2,578.50$ \\
1 & 2 & 859.50 & $2,578.50$ \\
1 & 3 & 644.63 & $2,578.50$ \\
1 & 4 & 515.70 & $2,578.50$ \\
1 & 24 & 192.32 & $4,808.00$ \\
\hline 0 & 2 & $1,374.59$ & $2,749.18$ \\
0 & 3 & 934.96 & $2,804.88$ \\
0 & 4 & 732.00 & $2,928.00$ \\
0 & 5 & 600.01 & $3,000.05$ \\
0 & 6 & 512.09 & $3,072.54$ \\
0 & 7 & 449.43 & $3,146.01$ \\
0 & 8 & 396.86 & $3,174.88$ \\
0 & 9 & 353.51 & $3,181.59$ \\
0 & 10 & 324.63 & $3,246.30$ \\
0 & 12 & 286.47 & $3,437.64$ \\
0 & 15 & 251.14 & $3,767.10$ \\
0 & 18 & 226.65 & $4,079.70$ \\
\hline \hline
\end{tabular}

Table 2.2: Descriptive VARIABles

Description of the variables. Purchases of a single product, made with the private label card, from May 2009 to May 2011

\begin{tabular}{cccc}
\hline \hline Variable & Explanation & Mean & Standard Error \\
\hline \hline Default & proportion of defaults & 0.0608 & - \\
Gender & proportion of females & 0.6656 & - \\
Age & in years & 44.2150 & 15.8905 \\
Education1dg & proportion $1^{\text {st }}$ degree & 0.3382 & - \\
Education2dg & proportion $2^{\text {nd }}$ degree & 0.5529 & - \\
Education3inc & pp.3 $3^{r d}$ degree incomplete & 0.0353 & - \\
Education3dg & proportion $3^{r d}$ degree & 0.0736 & - \\
Income & in 1,000 Reais & 1.1111 & 852.870 \\
Saldão & proportion of occurrence & 0.3329 & - \\
Down Payment & proportion of occurrence & 0.5675 & - \\
Interest & per month & 2.2956 & 2.3262 \\
Interest Occur. & occurrence of positive interest & 0.5122 & - \\
Positive Interest & per month & 4.4814 & 0.8762 \\
Monthly Payments & number of & 6.0943 & 3.5108 \\
Debt/Income & ratio & 0.8338 & 5.8129 \\
Payment Done & in Reais & 330.34 & 517.46 \\
\hline \hline
\end{tabular}


Table 2.3: Monthly Payments Occurrence

Occurrence of the number of monthly payments with positive and zero interest rates, percentage.

\begin{tabular}{ccc}
\hline \hline Number of Monthly Payments & $\begin{array}{c}\text { Proportion of } \\
\text { the Total }\end{array}$ & $\begin{array}{c}\text { Fraction with } \\
\text { Zero Interest }\end{array}$ \\
\hline 1 & 1.79 & 65.46 \\
2 & 15.20 & 61.05 \\
3 & 13.67 & 23.09 \\
4 & 6.60 & 42.22 \\
5 & 20.78 & 75.15 \\
6 & 4.55 & 4.78 \\
7 & 0.52 & 18.66 \\
8 & 4.19 & 1.93 \\
9 & 15.36 & 94.55 \\
10 & 2.91 & 3.07 \\
11 & 4.61 & 38.15 \\
12 & 8.76 & - \\
13 & 0.17 & - \\
14 & 0.02 & - \\
15 & 0.08 & - \\
16 & 0.01 & - \\
17 & 0.40 & - \\
18 & 0.24 & - \\
19 & - & - \\
20 & 0.04 & - \\
21 & - & - \\
22 & - & - \\
23 & - & - \\
24 & 0.10 & \\
\hline \hline
\end{tabular}


Table 2.4: Monthly Payments Occurrence, when "Saldão" Month Occurrence of the number of monthly payments with positive and zero interest rates, percentage, when it is "saldão" month.

\begin{tabular}{ccc}
\hline \hline Number of Monthly Payments & $\begin{array}{c}\text { Proportion of } \\
\text { the Total }\end{array}$ & $\begin{array}{c}\text { Fraction with } \\
\text { Zero Interest }\end{array}$ \\
\hline \hline 1 & 1.42 & 70.78 \\
2 & 10.84 & 61.02 \\
3 & 9.15 & 29.99 \\
4 & 4.48 & 52.04 \\
5 & 23.37 & 86.06 \\
6 & 3.19 & 13.69 \\
7 & 0.42 & 45.17 \\
8 & 1.96 & 8.26 \\
9 & 28.51 & 98.61 \\
10 & 5.10 & 5.27 \\
11 & 5.48 & 94.40 \\
12 & 5.22 & 0.00 \\
13 & 0.11 & 0.00 \\
14 & 0.01 & 0.00 \\
15 & 0.04 & 0.00 \\
16 & 0.01 & 0.00 \\
17 & 0.18 & 0.00 \\
18 & 0.07 & 0.00 \\
19 & 0.00 & 0.00 \\
20 & 0.02 & 0.00 \\
21 & 0.00 & 0.00 \\
22 & 0.00 & 0.00 \\
23 & 0.00 & 0.00 \\
24 & 0.06 & 0.00 \\
\hline \hline
\end{tabular}


Table 2.5: Monthly Payment Occurrence, When not "Saldão" MONTH

Occurrence of the number of monthly payments with positive and zero interest rates, percentage, when it is not "saldão" month.

\begin{tabular}{ccc}
\hline \hline Number of Monthly Payments & $\begin{array}{c}\text { Proportion of } \\
\text { the Total }\end{array}$ & $\begin{array}{c}\text { Fraction with } \\
\text { Zero Interest }\end{array}$ \\
\hline \hline 1 & 1.98 & 63.56 \\
2 & 17.38 & 61.05 \\
3 & 15.92 & 21.12 \\
4 & 7.49 & 39.06 \\
5 & 19.48 & 68.63 \\
6 & 5.22 & 2.06 \\
7 & 0.56 & 8.84 \\
8 & 5.30 & 0.76 \\
9 & 8.79 & 87.99 \\
10 & 1.82 & 0.00 \\
11 & 4.18 & 0.00 \\
12 & 10.52 & 0.00 \\
13 & 0.20 & 0.00 \\
14 & 0.03 & 0.00 \\
15 & 0.10 & 0.00 \\
16 & 0.01 & 0.00 \\
17 & 0.51 & 0.00 \\
18 & 0.32 & 0.00 \\
19 & 0.00 & 0.00 \\
20 & 0.06 & 0.00 \\
21 & 0.00 & 0.00 \\
22 & 0.00 & 0.00 \\
23 & 0.00 & 0.00 \\
24 & 0.13 & 0.00 \\
\hline \hline
\end{tabular}


Table 2.6: Characteristics Difference When "SAldẽo" And Not "SALDÃO"

Clients characteristics, when it is "saldão" and it is not "saldão" month.

\begin{tabular}{cccc}
\hline \hline Gender & General & "Saldão" & Non "Saldão" \\
\hline Men & $33.4 \%$ & $33.7 \%$ & $33.3 \%$ \\
Women & $66.6 \%$ & $66.3 \%$ & $66.7 \%$ \\
\hline \hline Education & General & "Saldão" & Non "Saldão" \\
\hline First Degree & $33.8 \%$ & $33.5 \%$ & $34.0 \%$ \\
Second Degree & $55.3 \%$ & $55.3 \%$ & $55.3 \%$ \\
Third Degree Incomplete & $3.5 \%$ & $3.5 \%$ & $3.5 \%$ \\
Third Degree & $7.4 \%$ & $7.8 \%$ & $7.1 \%$ \\
\hline \hline Income & General & "Saldão" & Non "Saldão" \\
\hline Mean & 1.11 & 1.13 & 1.10 \\
Standard Error & 0.85 & 0.86 & 0.85 \\
\hline \hline Interest & General & "Saldão" & Non "Saldão" \\
\hline Zero Interest & $48.8 \%$ & $67.5 \%$ & $39.5 \%$ \\
Positive Interest & $51.2 \%$ & $32.5 \%$ & $60.5 \%$ \\
\hline \hline
\end{tabular}


Table 2.7: Interest Rate Regression Result - First Stage

Results of the regression of the first stage when the interest rate is the dependent variable. OLS coefficients. Gender (1, when female), age (in years), age squared, education (dummy variables for $2^{\text {nd }}$ degree, $3^{\text {rd }}$ degree incomplete and $3^{\text {rd }}$ degree), income (in 1,000 Reais), yearly dummies, Debt/Income is the debt of the client with the chain store over income, Payment Done is the total amount the client has paid in the past to repay former debts and "Saldão is the exogenous variable used in the first stage(a dummy variable that is one when the month of the purchase is one of the "saldão" months, that is, when one special payment plan is also available). Robust standard errors in parentheses. Significance: $* * * \mathrm{p}<0.01$; ${ }^{* *} \mathrm{p}<0.05$ and ${ }^{*} \mathrm{p}<0.1$

\begin{tabular}{cc}
\hline \hline Variable & Coefficient \\
\hline \hline Constant & $3.566756^{* * *}$ \\
& $(0.007963)$ \\
Gender & $0.121720^{* * *}$ \\
& $(0.003809)$ \\
Age & $-0.001589^{* * *}$ \\
& $(0.000130)$ \\
Age Squared & $0.000000^{* * *}$ \\
& $(0.000000)$ \\
Education2dg & $-0.260018^{* * *}$ \\
& $(0.004079)$ \\
Education3inc & $-0.523741^{* * *}$ \\
& $(0.010078)$ \\
Education3dg & $-0.639650^{* * *}$ \\
& $(0.007437)$ \\
Income & $-0.257394^{* * *}$ \\
& $(0.002457)$ \\
D2010 & $-0.491164^{* * *}$ \\
& $(0.003987)$ \\
D2011 & $-0.457441^{* * *}$ \\
& $(0.007336)$ \\
Debt/Income & $0.002166^{* * *}$ \\
& $(0.000307)$ \\
Payment Done & $-0.000124^{* * *}$ \\
Saldão & $(0.000003)$ \\
& $-1.308628^{* * *}$ \\
R2 & $(0.003676)$ \\
\hline \hline & 0.1147 \\
Obs Number & $1,567,284$ \\
\hline &
\end{tabular}


Table 2.8: Interest Rate Regression Result - Second Stage

Results of the regression of the second stage - default probability. Probit regression and average marginal effects. Gender (1, when female), age (in years), age squared, education (dummy variables for $2^{\text {nd }}$ degree, $3^{\text {rd }}$ degree incomplete and $3^{r d}$ degree), income (in 1,000 Reais), yearly dummies, Debt/Income is the debt of the client with the chain store over income, Payment Done is the total amount the client has paid in the past to repay former debts, Interest is the interest rate per month and Non Observable is the residual of the first stage, that is client's non observable characteristics. Robust standard errors in parentheses. Significance: $* * * \mathrm{p}<0.01 ;{ }^{* *} \mathrm{p}<0.05$ and $*$ $\mathrm{p}<0.1$.

\begin{tabular}{|c|c|c|}
\hline Variable & Coefficient & Marginal Effect \\
\hline Constant & $\begin{array}{c}-0.888347^{* * *} \\
(0.011858)\end{array}$ & - \\
\hline Gender & $\begin{array}{c}-0.203906^{* * *} \\
(0.003457)\end{array}$ & $\begin{array}{c}-0.024689^{* * *} \\
(0.000438)\end{array}$ \\
\hline Age & $\begin{array}{c}-0.011945^{* * *} \\
(0.000134)\end{array}$ & $\begin{array}{c}-0.001382^{* * *} \\
(0.000016)\end{array}$ \\
\hline Age Squared & $\begin{array}{c}-0.000002^{* * *} \\
(0.000000)\end{array}$ & $\begin{array}{c}0.000000^{* * *} \\
(0.000000)\end{array}$ \\
\hline Education $2 \mathrm{dg}$ & $\begin{array}{c}-0.096412^{* * *} \\
(0.003880)\end{array}$ & $\begin{array}{c}-0.011261^{* * * *} \\
(0.000458)\end{array}$ \\
\hline Education3inc & $\begin{array}{c}-0.130519^{* * *} \\
(0.009418)\end{array}$ & $\begin{array}{c}-0.013798^{* * *} \\
(0.000906)\end{array}$ \\
\hline Education3dg & $\begin{array}{c}-0.055754^{* * *} \\
(0.007613)\end{array}$ & $\begin{array}{c}-0.006224^{* * *} \\
(0.000820)\end{array}$ \\
\hline Income & $\begin{array}{c}-0.016995^{* * *} \\
(0.002630)\end{array}$ & $\begin{array}{c}-0.001966^{* * *} \\
(0.000304)\end{array}$ \\
\hline D2010 & $\begin{array}{c}0.021401^{* * *} \\
(0.004240)\end{array}$ & $\begin{array}{c}0.002471^{* * *} \\
(0.000488)\end{array}$ \\
\hline D2011 & $\begin{array}{c}-0.316157^{* * *} \\
(0.009576)\end{array}$ & $\begin{array}{c}-0.029545^{* * *} \\
(0.000704)\end{array}$ \\
\hline Debt/Income & $\begin{array}{c}0.003788^{* * *} \\
(0.000243)\end{array}$ & $\begin{array}{c}0.000438^{* * *} \\
(0.000028)\end{array}$ \\
\hline Payment Done & $\begin{array}{c}-0.000227^{* * *} \\
(0.000006)\end{array}$ & $\begin{array}{c}-0.000026^{* * *} \\
(0.000001)\end{array}$ \\
\hline Interest & $\begin{array}{c}0.044141^{* * *} \\
(0.002769)\end{array}$ & $\begin{array}{c}0.005106^{* * *} \\
(0.000321)\end{array}$ \\
\hline Non Observable & $\begin{array}{c}0.020494^{* * *} \\
(0.002893)\end{array}$ & $\begin{array}{c}0.002371^{* * *} \\
(0.000335)\end{array}$ \\
\hline $\begin{array}{c}\text { Pseudo R2 } \\
\text { Obs Number }\end{array}$ & $\begin{array}{c}0.0447 \\
1,567,284\end{array}$ & \\
\hline
\end{tabular}


Table 2.9: Number of Monthly Payments Regression Result - First STAGE

Results of the regression of the first stage when the number of monthly payments the dependent variable. OLS coefficients. Gender (1, when female), age (in years), age squared, education (dummy variables for $2^{\text {nd }}$ degree, $3^{\text {rd }}$ degree incomplete and $3^{\text {rd }}$ degree), income (in 1,000 Reais), yearly dummies, Debt/Income is the debt of the client with the chain store over income, Payment Done is the total amount the client has paid in the past to repay former debts and "Saldão is the exogenous variable used in the first stage(a dummy variable that is one when the month of the purchase is one of the "saldão" months, that is, when one special payment plan is also available). Robust standard errors in parentheses. Significance: *** $\mathrm{p}<0.01 ;{ }^{* *} \mathrm{p}<0.05$ and ${ }^{*} \mathrm{p}<0.1$.

\begin{tabular}{cc}
\hline \hline Variable & Coefficient \\
\hline \hline Constant & $7.705120^{* * *}$ \\
& $(0.012874)$ \\
Gender & $-0.536619^{* * *}$ \\
& $(0.005850)$ \\
Age & $-0.011456^{* * *}$ \\
& $(0.000200)$ \\
Age Squared & $-0.000001^{* * *}$ \\
& $(0.000000)$ \\
Education2dg & $-0.337703^{* * *}$ \\
& $(0.006261)$ \\
Education3inc & $-0.463271^{* * *}$ \\
& $(0.015191)$ \\
Education3dg & $-0.565687^{* * *}$ \\
& $(0.011033)$ \\
Income & $-0.093813^{* * *}$ \\
& $(0.003375)$ \\
D2010 & $-0.835293^{* * *}$ \\
& $(0.006308)$ \\
D2011 & $-3.479951^{* * *}$ \\
& $(0.008792)$ \\
Debt/Income & $0.045369^{* * *}$ \\
& $(0.002531)$ \\
Payment Done & $-0.000264^{* * *}$ \\
Saldão & $(0.000004)$ \\
& $1.141741^{* * *}$ \\
R2 & $(0.005482)$ \\
\hline Obs Number & 0.0984 \\
& $1,567,284$ \\
\hline
\end{tabular}


Table 2.10: Number of Monthly Payments Regression Result SECOND Stage

Results of the regression of the second stage - default probability. Probit regression and average marginal effects. Gender (1, when female), age (in years), age squared, education (dummy variables for $2^{\text {nd }}$ degree, $3^{\text {rd }}$ degree incomplete and $3^{\text {rd }}$ degree), income (in 1,000 Reais), yearly dummies, Debt/Income is the debt of the client with the chain store over income, Payment Done is the total amount the client has paid in the past to repay former debts, Monthly Payments is the number of payments chosen and Non Observable is the residual of the first stage, that is client's non observable characteristics. Robust standard errors in parentheses. Significance: ${ }^{* *} \mathrm{p}<0.01 ;{ }^{* *} \mathrm{p}<0.05$ and ${ }^{*} \mathrm{p}<0.1$.

\begin{tabular}{|c|c|c|}
\hline Variable & Coefficient & Marginal Effect \\
\hline \multirow[t]{2}{*}{ Constant } & $\overline{-0.456994^{* * *}}$ & - \\
\hline & $(0.026388)$ & - \\
\hline \multirow[t]{2}{*}{ Gender } & $-0.229117 * * *$ & $-0.026193^{* * *}$ \\
\hline & $(0.003899)$ & $(0.000484)$ \\
\hline \multirow[t]{2}{*}{ Age } & $-0.012691^{* * *}$ & $-0.001426 * * *$ \\
\hline & $(0.000140)$ & $(0.000016)$ \\
\hline \multirow[t]{2}{*}{ Age Squared } & $-0.000002^{* * *}$ & $0.000000 * * *$ \\
\hline & $(0.000000)$ & $(0.000000)$ \\
\hline \multirow[t]{2}{*}{ Education2dg } & $-0.120591^{* * *}$ & $-0.013717^{* * *}$ \\
\hline & $(0.004003)$ & $(0.000461)$ \\
\hline \multirow[t]{2}{*}{ Education3inc } & $-0.168393^{* * *}$ & $-0.016895^{* * *}$ \\
\hline & $(0.009559)$ & $(0.000850)$ \\
\hline \multirow[t]{2}{*}{ Education3dg } & $-0.102139 * * *$ & $-0.010771^{* * *}$ \\
\hline & $(0.007685)$ & $(0.000759)$ \\
\hline \multirow[t]{2}{*}{ Income } & $-0.031893^{* * *}$ & $-0.003583^{* * *}$ \\
\hline & $(0.002635)$ & $(0.000296)$ \\
\hline \multirow[t]{2}{*}{ D2010 } & $-0.024970 * * *$ & $-0.002813^{* * *}$ \\
\hline & $(0.004189)$ & $(0.000473)$ \\
\hline \multirow[t]{2}{*}{ D2011 } & $-0.429675^{* * *}$ & $-0.036552^{* * *}$ \\
\hline & $(0.013425)$ & $(0.000831)$ \\
\hline \multirow[t]{2}{*}{ Debt/Income } & $0.007230^{* * *}$ & $0.000812^{* * *}$ \\
\hline & $(0.000253)$ & $(0.000029)$ \\
\hline \multirow[t]{2}{*}{ Payment Done } & $-0.000231^{* * *}$ & $-0.000026^{* * *}$ \\
\hline & $(0.000006)$ & $(0.000001)$ \\
\hline \multirow[t]{2}{*}{ Monthly Payments } & $-0.041620 * * *$ & $-0.004676^{* * *}$ \\
\hline & $(0.003200)$ & $(0.000360)$ \\
\hline \multirow[t]{2}{*}{ Non Observable } & $0.118903^{* * *}$ & $0.013359^{* * *}$ \\
\hline & $(0.003220)$ & $(0.000362)$ \\
\hline Pseudo R2 & 0.0729 & \\
\hline Obs Number & $1,567,284$ & \\
\hline
\end{tabular}


Table 2.11: Average Marginal Effects Comparison

Marginal Effects of the regression of the second stage - default probability. Average marginal effects. Gender (1, when female), age (in years), age squared, education (dummy variables for $2^{\text {nd }}$ degree, $3^{\text {rd }}$ degree incomplete and $3^{\text {rd }}$ degree), income (in 1,000 Reais), yearly dummies, Debt/Income is the debt of the client with the chain store over income, Payment Done is the total amount the client has paid in the past to repay former debts, Monthly Payments is the number of payments chosen and Non Observable is the residual of the first stage, that is client's non observable characteristics. Robust standard errors in parentheses. Significance: ${ }^{* * *} \mathrm{p}<0.01 ;{ }^{* *} \mathrm{p}<0.05$ and ${ }^{*} \mathrm{p}<0.1$.

\begin{tabular}{ccc}
\hline \hline Variable & Positive Interest & Zero Interest \\
& Marginal Effect & Marginal Effect \\
\hline \hline Gender & $-0.018424^{* * *}$ & $-0.024283^{* * *}$ \\
Age & $(0.000531)$ & $(0.000557)$ \\
& $-0.003480^{* * *}$ & $-0.000802^{* * *}$ \\
Age Squared & $(0.000093)$ & $(0.000119)$ \\
& $0.000020^{* * *}$ & -0.000001 \\
Education2dg & $(0.000001)$ & $(0.000001)$ \\
& $-0.010307^{* * *}$ & $-0.009854^{* * *}$ \\
Education3inc & $(0.000534)$ & $(0.000655)$ \\
& $-0.014675^{* * *}$ & $-0.009802^{* * *}$ \\
Education3dg & $(0.001193)$ & $(0.001354)$ \\
& $-0.007367^{* * *}$ & $-0.002887^{* *}$ \\
Income & $-0.003687^{* * *}$ & $(0.001118)$ \\
& $(0.000452)$ & $\left(0.001168^{* * *}\right.$ \\
D2010 & $0.004516^{* * *}$ & $0.001855^{* * *}$ \\
& $(0.000609)$ & $(0.000719)$ \\
D2011 & $0.005284^{* * *}$ & $-0.038514^{* * *}$ \\
& $(0.001799)$ & $(0.000967)$ \\
Debt/Income & $0.000229^{* * *}$ & $0.000876^{* * *}$ \\
& $(0.000035)$ & $(0.000042)$ \\
Payment Done & $-0.000026^{* * *}$ & $-0.000022^{* * *}$ \\
& $(0.000001)$ & $(0.000001)$ \\
Monthly Payments & $0.007287^{* * *}$ & $-0.006015^{* * *}$ \\
& $(0.000438)$ & $(0.000426)$ \\
Non Observable & $0.001152^{* * *}$ & $0.013222^{* * *}$ \\
& $(0.000437)$ & $(0.000462)$ \\
\hline Pseudo R2 & 0.0784 & \\
Obs Number & $1,567,284$ & \\
\hline \hline
\end{tabular}


Table 2.12: Interest Rate Regression Result - Second Stage Without the Non Observable

Results of the regression of the second stage - default probability. Probit regression and average marginal effects. Gender (1, when female), age (in years), age squared, education (dummy variables for $2^{\text {nd }}$ degree, $3^{\text {rd }}$ degree incomplete and $3^{\text {rd }}$ degree), income (in 1,000 Reais), yearly dummies, Debt/Income is the debt of the client with the chain store over income, Payment Done is the total amount the client has paid in the past to repay former debts and Interest is the interest rate per month. Robust standard errors in parentheses. Significance: $* * * \mathrm{p}<0.01 ; * * \mathrm{p}<0.05$ and ${ }^{*} \mathrm{p}<0.1$.

\begin{tabular}{ccc}
\hline \hline Variable & Coefficient & Marginal Effect \\
\hline \hline Constant & $-0.951401^{* * *}$ & - \\
& $(0.007779)$ & - \\
Gender & $-0.206283^{* * *}$ & $-0.024994^{* * *}$ \\
& $(0.003443)$ & $(0.000437)$ \\
Age & $-0.011898^{* * *}$ & $-0.001376^{* * *}$ \\
& $(0.000134)$ & $(0.000016)$ \\
Age Squared & $-0.000002^{* * *}$ & $0.000000^{* * *}$ \\
& $(0.000000)$ & $(0.000000)$ \\
Education2dg & $-0.091325^{* * *}$ & $-0.010661^{* * *}$ \\
& $(0.003805)$ & $(0.000448)$ \\
Education3inc & $-0.120304^{* * *}$ & $-0.012809^{* * *}$ \\
& $(0.009302)$ & $(0.000908)$ \\
Education3dg & $-0.043220^{* * *}$ & $-0.004864^{* * *}$ \\
& $(0.007384)$ & $(0.000808)$ \\
Income & $-0.011739^{* * *}$ & $-0.001358^{* * *}$ \\
& $(0.002525)$ & $(0.000292)$ \\
D2010 & $0.034998^{* * *}$ & $0.004036^{* * *}$ \\
& $(0.003706)$ & $(0.000426)$ \\
D2011 & $-0.298090^{* * *}$ & $-0.028195^{* * *}$ \\
& $(0.009139)$ & $(0.000690)$ \\
Debt/Income & $0.003761^{* * *}$ & $0.000435^{* * *}$ \\
& $(0.000244)$ & $(0.000028)$ \\
Payment Done & $-0.000227^{* * *}$ & $-0.000026^{* * *}$ \\
& $(0.000006)$ & $(0.000001)$ \\
Interest & $0.063179^{* * *}$ & $0.007309^{* * *}$ \\
& $(0.000725)$ & $(0.000085)$ \\
\hline Pseudo R2 & 0.0447 & \\
\hline \hline
\end{tabular}


Table 2.13: Interest Rate Regression Result - Second Stage Without the Interest Rate

Results of the regression of the second stage - default probability. Probit regression and average marginal effects. Gender (1, when female), age (in years), age squared, education (dummy variables for $2^{\text {nd }}$ degree, $3^{\text {rd }}$ degree incomplete and $3^{\text {rd }}$ degree), income (in 1,000 Reais), yearly dummies, Debt/Income is the debt of the client with the chain store over income, Payment Done is the total amount the client has paid in the past to repay former debts and Non Observable is the residual of the first stage, that is client's non observable characteristics. Robust standard errors in parentheses. Significance: ${ }^{* * *}$ $\underline{\mathrm{p}<0.01 ; * *} \mathrm{p}<0.05$ and $* \mathrm{p}<0.1$.

\begin{tabular}{ccc}
\hline \hline Variable & Coefficient & Marginal Effect \\
\hline \hline Constant & $-0.740796^{* * *}$ & - \\
& $(0.007435)$ & - \\
Gender & $-0.198338^{* * *}$ & $-0.023989^{* * *}$ \\
& $(0.003440)$ & $(0.000435)$ \\
Age & $-0.012057^{* * *}$ & $-0.001395^{* * *}$ \\
& $(0.000134)$ & $(0.000016)$ \\
Age Squared & $-0.000002^{* * *}$ & $0.000000^{* * *}$ \\
& $(0.000000)$ & $(0.000000)$ \\
Education2dg & $-0.108210^{* * *}$ & $-0.012662^{* * *}$ \\
& $(0.003803)$ & $(0.000450)$ \\
Education3inc & $-0.154341^{* * *}$ & $-0.016056^{* * *}$ \\
& $(0.009297)$ & $(0.000863)$ \\
Education3dg & $-0.085019^{* * *}$ & $-0.009319^{* * *}$ \\
& $(0.007374)$ & $(0.000764)$ \\
Income & $-0.029350^{* * *}$ & $-0.003396^{* * *}$ \\
& $(0.002521)$ & $(0.000292)$ \\
D2010 & $-0.010590^{* * *}$ & $-0.001227^{* * *}$ \\
& $(0.003670)$ & $(0.000426)$ \\
D2011 & $-0.358549^{* * *}$ & $-0.032591^{* * *}$ \\
& $(0.009123)$ & $(0.000630)$ \\
Debt/Income & $0.003846^{* * *}$ & $0.000445^{* * *}$ \\
& $(0.000241)$ & $(0.000028)$ \\
Payment Done & $-0.000227^{* * *}$ & $-0.000026^{* * *}$ \\
& $(0.000006)$ & $(0.000001)$ \\
Non Observable & $0.064848^{* * *}$ & $0.007504^{* * *}$ \\
& $(0.000758)$ & $(0.000088)$ \\
\hline Pseudo R2 & 0.0444 & \\
Obs Number & $1,567,284$ & \\
\hline \hline
\end{tabular}


Table 2.14: Average Marginal Effects Comparison - Without the Non OBSERVABLE

Marginal Effects of the regression of the second stage - default probability. Average marginal effects. Gender (1, when female), age (in years), age squared, education (dummy variables for $2^{\text {nd }}$ degree, $3^{\text {rd }}$ degree incomplete and $3^{\text {rd }}$ degree), income (in 1,000 Reais), yearly dummies, Debt/Income is the debt of the client with the chain store over income, Payment Done is the total amount the client has paid in the past to repay former debts and Monthly Payments is the number of payments chosen. Robust standard errors in parentheses. Significance: ${ }^{* * *} \mathrm{p}<0.01$; ** $\mathrm{p}<0.05$ and $* \mathrm{p}<0.1$.

\begin{tabular}{ccc}
\hline \hline & Positive Interest & Zero Interest \\
Variable & Marginal Effect & Marginal Effect \\
\hline \hline Gender & $-0.015900^{* * *}$ & $-0.020400^{* * *}$ \\
Age & $(0.000499)$ & $(0.000525)$ \\
& $\left(0.001119^{* * *}\right.$ & $-0.001049^{* * *}$ \\
Age Squared & $-0.0000063^{* * *}$ & $(0.000022)$ \\
& $(0.000001)$ & $\left(0.000000^{* * *}\right.$ \\
Education2dg & $-0.005743^{* * *}$ & $-0.010934^{* * *}$ \\
& $(0.000525)$ & $(0.000621)$ \\
Education3inc & $-0.008249^{* * *}$ & $-0.010964^{* * *}$ \\
& $(0.001296)$ & $(0.001310)$ \\
Education3dg & $-0.005110^{* * *}$ & 0.000160 \\
& $(0.001186)$ & $(0.001128)$ \\
Income & $-0.003428^{* * *}$ & -0.000403 \\
& $(0.000445)$ & $(0.000369)$ \\
D2010 & $0.007872^{* * *}$ & $0.007500^{* * *}$ \\
& $(0.000556)$ & $(0.000675)$ \\
D2011 & $0.002503^{*}$ & $-0.018085^{* * *}$ \\
& $(0.001458)$ & $(0.001167)$ \\
Debt/Income & $0.000182^{* * *}$ & $0.000274^{* * *}$ \\
& $(0.000029)$ & $(0.000036)$ \\
Payment Done & $-0.000026^{* * *}$ & $-0.000017^{* * *}$ \\
& $(0.000001)$ & $(0.000001)$ \\
Monthly Payments & $0.008906^{* * *}$ & $-0.005201^{* * *}$ \\
& $(0.000059)$ & $(0.000096)$ \\
\hline Pseudo R2 & 0.0761 & \\
Obs Number & $1,567,284$ & \\
\hline \hline
\end{tabular}




\section{Table 2.15: Average Marginal Effects Comparison - Without} Monthly PAYMENTS

Marginal Effects of the regression of the second stage - default probability. Average marginal effects. Gender (1, when female), age (in years), age squared, education (dummy variables for $2^{\text {nd }}$ degree, $3^{\text {rd }}$ degree incomplete and $3^{\text {rd }}$ degree), income (in 1,000 Reais), yearly dummies, Debt/Income is the debt of the client with the chain store over income, Payment Done is the total amount the client has paid in the past to repay former debts and Non Observable is the residual of the first stage, that is client's non observable characteristics. Robust standard errors in parentheses. Significance: ${ }^{* * *} \mathrm{p}<0.01$; ** $\mathrm{p}<0.05$ and $* \mathrm{p}<0.1$.

\begin{tabular}{ccc}
\hline \hline & Positive Interest & Zero Interest \\
Variable & Marginal Effect & Marginal Effect \\
\hline \hline Gender & $-0.019901^{* * *}$ & $-0.023976^{* * *}$ \\
& $(0.000495)$ & $(0.000516)$ \\
Age & $-0.000410^{* * *}$ & $-0.001199^{* * *}$ \\
& $(0.000063)$ & $(0.000023)$ \\
Age Squared & $-0.000012^{* * *}$ & $-0.000000^{* * *}$ \\
& $(0.000001)$ & $(0.000000)$ \\
Education2dg & $-0.007387^{* * *}$ & $-0.014816^{* * *}$ \\
& $(0.000521)$ & $(0.000606)$ \\
Education3inc & $-0.010082^{* * *}$ & $-0.015765^{* * *}$ \\
& $(0.001256)$ & $(0.001220)$ \\
Education3dg & $-0.009457^{* * *}$ & $-0.004838^{* * *}$ \\
& $(0.001113)$ & $(0.001067)$ \\
Income & $-0.0041937^{* * *}$ & $-0.001335^{* * *}$ \\
& $(0.000441)$ & $(0.000378)$ \\
D2010 & $0.002448^{* * *}$ & $0.002038^{* * *}$ \\
& $(0.000540)$ & $(0.000657)$ \\
D2011 & $0.021087^{* * *}$ & $-0.030425^{* * *}$ \\
& $(0.001020)$ & $(0.000919)$ \\
Debt/Income & $0.000590^{* * *}$ & $0.000557^{* * *}$ \\
& $(0.000029)$ & $(0.000036)$ \\
Payment Done & $-0.000030^{* * *}$ & $-0.000019^{* * *}$ \\
& $(0.000001)$ & $(0.000001)$ \\
Non Observable & $0.008561^{* * *}$ & $0.007098^{* * *}$ \\
& $(0.000060)$ & $(0.000108)$ \\
\hline Pseudo R2 & 0.0757 & \\
Obs Number & $1,567,284$ & \\
\hline \hline
\end{tabular}




\section{The Effect of Taxation on Prices and Sales of a Kitchen and Home Appliance Store}

This paper studies the effect of the first IPI (Industrialized Product Tax) reduction of 2009 (from April $17^{\text {th }}$ to October $31^{\text {st }}$ ) on prices and sales in a kitchen and home appliance store. This tax reduction was one of the government actions to fight the consequences of the 2008 crisis. According to the Government, the objective of the reduction is primarily to increase sales, what we actually observe. We estimate the pass through to prices and investigate the effect of the reduction on the composition of the client base.

Estimating the effect of the tax reduction on prices is important both to evaluate the effectiveness and the welfare implications of this particular policy and because the pass-through parameter is an important piece of information to investigate conduct in the retail market (Farrell \& Shapiro (2010), Weyl \& Fabinger (2012)). We expected a $7.5 \%$ average price reduction if the pass through was complete, but we find a $2.98 \%$ price reduction. We do not find significant changes on client base, what could have represented a inclusion policy.

Poterba (1996) tests the hypothesis that retail sales taxes are fully shifted to consumers. In his case, the tax change is a increase. He includes clothing price indices for eight cities during the postwar and fourteen cities during the Depression period. The results for the first period suggest that retail prices rise by approximately the amount of the sales tax and for the second period, prices appear to rise by only two-thirds of the amount of sales taxes. Doyle \& Samphantharak (2008) consider the temporary suspension, and subsequent reinstatement, of the gasoline sales tax in Illinois and Indiana. Using data set of daily prices at the gas-station level, they found that $70 \%$ of the tax suspension is passed on to consumers in the form of lower prices, while $80 \%$ to $100 \%$ of the tax reinstatements are passed on to consumers. This means that retail gas prices are found to drop by $3 \%$ following the elimination of the $5 \%$ sales tax, and increase by $4 \%$ following the reinstatements, compared to neighboring states. Borenstein et al. (1997) also use retail gasoline data and confirm that prices respond more quickly to increases than to decreases in crude oil prices and wholesale prices. Besley \& Rosen (1999) use specific commodity prices 
to examine how differences in tax rates are reflected in prices. Kenkel (2005) evaluates the impact of a tax hike on alcoholic beverage prices.

Section 3.1 describes the data base. Section 3.2 explains the IPI tax and its reduction policy. Section 3.3 presents the regressions. Section 3.4 shows the results of the IPI effect on prices. Section 3.5 shows the IPI effect on clients' characteristics. Finally, Section 3.6 concludes.

\subsection{Data}

Our database includes data from January 2006 to October 2009, from a kitchen and home appliance store. It includes only purchases of a single product.

The products analyzed are in fact a subgroup of the totality of products sold at the store in question (they represented approximately $7.5 \%$ of the store's profits). The products considered are from two groups: kitchen appliance and home appliance. The first group includes wine cellar, chimney kitchen cooker hood extractor, cook top, kitchen depurator, built-in cooker, freestanding cooker, electric oven, horizontal freezer, vertical freezer, fridge-bar, dishwasher, microwave, one door refrigerator, automatic defrost two doors refrigerator, frost free two doors refrigerator and side by side refrigerator. The second group includes wall air conditioning, split air conditioning, spin-dryer, conventional drying machine, electronic climate control, dehumidifying machine, automatic washing machine and semi-automatic washing machine.

From those products the ones that had their IPI reduced are: refrigerators, cookers, washing machines and "tanquinhos" (which is a washing machine with limited functions). Table 3.1 shows the reduction.

\subsection{The Industrialized Products Tax Stimulus}

In order to stimulate kitchen and home appliance sales, the government reduced some industrialized product taxes of four specific products: refrigerators, cookers, washing machines and "tanquinhos" (which is a washing machine with limited functions). The decision was announced on April $17^{\text {th }}$, 2009. First, the reduction would be until July 2009, but in the end, the first part of it (the one we are studying, with flat reduction) was extended until October $31^{\text {st }}$, 2009. There was also a second reduction period with differentiated taxes, but we do not analyze this one, because we would need to known a specific product characteristic that is not available in the database.

The IPI - Industrialized Products Tax - is paid in two cases: domestic and imported industrialized products. The tax rate is calculated on the total value of the product when it leaves the industrial place and on the value of the 
imported product plus other taxes, respectively. There are different tax rates, depending on the product ${ }^{1}$.

To calculate the reduction that would occur in prices, if the reduction pass through was complete, we did the following calculations:

$$
\begin{gathered}
p p_{j t} \times I P I_{j t} \times t_{j t} \times m_{j t}=c p_{j t} \\
p p_{j t+1} \times I P I_{j t+1} \times t_{j t+1} \times m_{j t+1}=c p_{j t+1}
\end{gathered}
$$

, where $p p$ is the producer price of product $j$ at time $t$, IPI is the Industrialized Products Tax, $\mathrm{t}$ is other taxes and $\mathrm{m}$ is transport and commerce margins. $t$ is the period with the original IPI and $t+1$ the period with the reduced IPI. We consider there was no change on producer price, other taxes or margins, then we have:

$$
\begin{gathered}
p p_{j t}=p p_{j t+1} \\
c p_{j t} /\left[I P I_{j t} \times t_{j t} \times m_{j t}\right]=c p_{j t+1} /\left[I P I_{j t+1} \times t_{j t+1} \times m_{j t+1}\right]
\end{gathered}
$$

Rearranging:

$$
c p_{j t+1}=c p_{j t} \times\left[I P I_{j t+1} \times t_{j t+1} \times m_{j t+1}\right] /\left[I P I_{j t} \times t_{j t} \times m_{j t}\right]
$$

Since $t_{j t}=t_{j t+1}$ and $m_{j t}=m_{j t+1}$ :

$$
c p_{j t+1}=c p_{j t} \times\left[I P I_{j t+1} / I P I_{j t}\right]
$$

If we consider transport and commerce margins in a additive way (instead of multiplicative), the calculations is analogous.

Table 3.2 shows the results of the calculations. If it was the case that the pass through was complete, the reduction in prices should be $8.70 \%$ for refrigerators, $3.85 \%$ for cookers, $8.33 \%$ for washing machines and $9.0 \%$ for "tanquinhos", resulting in a $7.5 \%$ average reduction.

As said before, the purpose of the tax reduction was to stimulate sales. Before estimating the tax reduction pass through, we calculate if the government decision has achieved its objective, that is, if it increased the sales. Table 3.3 shows average sales before and during IPI reduction period for reduced IPI products and others. We sum all the purchases of the four reduced IPI products and all other products for the periods before and during the IPI reduction and calculated the average sales dividing that sum by 39.5 and 6.5 months, respectively. Than we calculated the increase of the sales. We actually find that sales of the products with reduced IPI increased $67.44 \%$ while sales of other products decreased $20.92 \%$.

\footnotetext{
${ }^{1}$ Taxes can be found on the IPI Table (TIPI - in Portuguese, at http://www.receita.fazenda.gov.br/Aliquotas/DownloadArqTIPI.htm).
} 


\subsection{Estimation}

We calculated what would be the IPI effect on prices if the reduction pass through was complete. Now we want to estimate what was the actual effect. The first regression is a linear one. The logarithm of the price of the product is the dependent variable. As independent variables we have the IPI date dummy (which is one when the date of the purchase is inside the IPI reduction period), the IPI product variable (which is equal to one when ir is a product which tax suffered the reduction), the IPI effect reduction dummy (which is the product of the IPI date dummy and the IPI product variable, and which coefficient we are interest in), the product section dummy (home appliance or kitchen appliance), "saldão" month dummy ${ }^{2}$ and dummies of the quarter and the year.

$$
\operatorname{Ln}(\text { Price })_{j t}=\beta_{0}+e_{j t} \beta_{1}+p_{j} \beta_{2}+d_{t} \beta_{3}++h_{j t} \beta_{4}+s_{j t} \beta_{5}+T_{j t}^{\prime} \beta_{6}+Y_{j t}^{\prime} \beta_{7}+\epsilon_{j t}
$$

, where $\operatorname{Ln}(\text { Price })_{j t}$ is logarithm of the price of the product $j$ at time $t . e_{j} t$ is the IPI effect dummy, $p_{j} t$ is the IPI product dummy, $d_{j} t$ is the IPI date dummy, $h_{j} t$ is the section dummy and $s_{j} t$ is the 'Saldão" dummy. $T_{t}$ is the vector of trimester dummy variables and $Y_{t}$ is the vector of yearly dummy variables. $\epsilon_{j t}$ is the zero mean idiosyncratic error.

We also run fixed effect regressions to account for the fact that the change in prices could be caused by something specific of the product. The dependent and independent variable are the same as the linear regression. The variable chosen to indicate the product is the product code. This code is different for each different product. If the brand is different, the color, or any other specification this code differs.

The estimated equation is:

$$
\operatorname{Ln}\left(\text { Price }_{j t}=\beta_{0}+e_{j t} \beta_{1}+p_{j} \beta_{2}+d_{t} \beta_{3}++h_{j t} \beta_{4}+s_{j t} \beta_{5}+T_{j t}^{\prime} \beta_{6}+Y_{j t}^{\prime} \beta_{7}+F E_{j}^{\prime} \beta_{8}+\epsilon_{j t}\right.
$$

, where $F E_{j}^{\prime}$ is vector of product code dummies.

We also want to investigate the effect of the stimulus on the composition of the consumer base. It could be the case that the IPI reduction allows clients with lower income, for example, to buy. To investigate this second effect, we run fixed effect regressions using the client's characteristics as the dependent variables.

\footnotetext{
${ }^{2}$ a dummy variable that is one when the month of the purchase is one of the "saldão" months (January, April or September), that is, when one special payment plan is also available
} 


\subsection{IPI Effect on Prices}

The first analysis wants to find the effect of the IPI reduction on the prices paid. The first column of results on Table 3.4 shows the results of a simplest linear regression. There is no fixed effects and the IPI product variable is a dummy one. The occurrence of the reduction produces a $5.97 \%$ reduction of the price. We can notice that being one of the products that suffered the reduction increases the price by $72.07 \%$ and being on the reduction period increases the price by $6.15 \%$. These results reinforce the IPI reduction effect. All coefficients are significant. The second column of results shows the results of the regression with the same IPI product variable but including product fixed effects. The occurrence of the reduction produces a $2.98 \%$ reduction of the price. The IPI product dummy is dropped (it does not vary for the same products) and being on the reduction period increases the price by $2.67 \%$.

\subsection{IPI Effect on Clients' Characteristics}

Table 3.5 shows the results of the regression when the age is the dependent variable. The only effect related to the IPI that is significant is that when it is the IPI reduction period there is a increase of 12.39 years on average. The IPI reduction does not affect the age composition of the clients that buy the products with reduced taxes. For gender, when the product is bought with the IPI reduction there is an increase of 0.46 percentage points in the probability that the client is a woman. Being at the IPI reduction period independently of the product bought increases this probability by 0.87 percentage points. Table 3.5 also shows the results for income and education. In both cases the IPI effects are not significant. During the IPI reduction period there are no significant changes in clients' income or education, on average.

\subsection{Conclusion}

The IPI reduction of 2009 (from April $17^{\text {th }}$ to October $31^{\text {st }}$ ) was followed by sales increase. We estimated the pass through to prices and investigate the effect of the reduction on clients' characteristics. Since the policy did not intend to simply decrease taxation of the sellers or to allow producers to increase prices, but it intended to decrease prices, the most important question was if it was working. On the other hand, even if sales increase did not lead to lower unemployment rates, it could be the case that the proposed policy changed the the main consumer characteristics, acting as a inclusive one. We expected a $7.5 \%$ average price reduction, if the pass through was complete, but we found a $2.98 \%$ price reduction. Besides that, we did not find significant changes 
on clients' characteristics, like income or education, that could represent a inclusion policy. 
Table 3.1: IPI REDUCTION

Products with IPI reduction.

\begin{tabular}{ccc}
\hline \hline Products & Until April $17^{\text {th }}, 2009$ & From April $17^{\text {th }}$ to October $31^{\text {st }}, 2009$ \\
\hline \hline Refrigerator & $15 \%$ & $5 \%$ \\
Cooker & $4 \%$ & $0 \%$ \\
Washing Machine & $20 \%$ & $10 \%$ \\
"Tanquinho" & $10 \%$ & $0 \%$ \\
\hline \hline
\end{tabular}

Table 3.2: IPI TABLE

Reduction calculations

\begin{tabular}{cccccc}
\hline \hline Products & $I P I_{j t}$ & $I P I_{j t+1}$ & $I P I_{j t+1} / I P I_{j t}$ & Reduction & Weight \\
\hline \hline Refrigerator & 1.15 & 1.05 & 0.9130 & $8.70 \%$ & $32.27 \%$ \\
Cooker & 1.04 & 1.00 & 0.9615 & $3.85 \%$ & $22.61 \%$ \\
Washing Machine & 1.20 & 1.10 & 0.9167 & $8.33 \%$ & $31.95 \%$ \\
"Tanquinho" & 1.10 & 1.00 & 0.9091 & $9.09 \%$ & $13.16 \%$ \\
\hline Simple Average & $7.49 \%$ & & & & \\
Weighted Average & $7.54 \%$ & & & & \\
\hline \hline
\end{tabular}

Table 3.3: Comparing Average Sales

The comparison of average sales before and during the IPI reduction period

\begin{tabular}{cccc}
\hline \hline Product & Before & During & Increase \\
\hline \hline Products with IPI Reduction & $9,907,263.24$ & $16,589,104.03$ & $67.44 \%$ \\
Cooker & $1,667,304.68$ & $1,811,561.07$ & $8.65 \%$ \\
Refrigerator & $4,491,880.62$ & $6,762,190.39$ & $50.54 \%$ \\
Washing Machine & $3,356,584.87$ & $7,418,536.12$ & $121.01 \%$ \\
"Tanquinho" & $391,493.07$ & $596,816.44$ & $52.45 \%$ \\
\hline Products Without IPI Reduction & $10,417,155.29$ & $8,237,421.96$ & $-20.92 \%$ \\
\hline \hline
\end{tabular}


Table 3.4: Price Paid OLS and Fixed Effect Regression Results Results of the OLS and FE regressions of the logarithm of the price paid. IPI effect is a dummy that is one when it is IPI period and the product bought is one with the reduced tax, Product with IPI Reduction is a dummy that is one when the product bought is one with the reduced tax, IPI Reduction Period is a dummy that is one when it is IPI period, Sector Dummy is a dummy that is one when the product is form the home appliance sector, "Saldão is the exogenous variable used in the first stage(a dummy variable that is one when the month of the purchase is one of the "saldão" months, that is, when one special payment plan is also available), dummies of trimester and yearly dummies. Robust standard errors in parentheses. Significance: ${ }^{* *} \mathrm{p}<0.01 ;{ }^{*} \mathrm{p}<0.05$ and ${ }^{*} \mathrm{p}<0.1$.

\begin{tabular}{|c|c|c|}
\hline $\begin{array}{l}\text { Estimation } \\
\text { Variable }\end{array}$ & $\begin{array}{c}\text { OLS } \\
\text { Coefficient }\end{array}$ & $\begin{array}{c}\text { Fixed Effects } \\
\text { Coefficient }\end{array}$ \\
\hline IPI Effect & $\begin{array}{c}-0.0597^{* * *} \\
(0.0032)\end{array}$ & $\begin{array}{c}-0.0298^{* * *} \\
(0.0007)\end{array}$ \\
\hline Product with IPI Reduction & $\begin{array}{c}0.7207^{* * *} \\
(0.0013\end{array}$ & dropped \\
\hline IPI Reduction Period & $\begin{array}{c}0.0615^{* * *} \\
(0.0031)\end{array}$ & $\begin{array}{c}0.0267^{* * * *} \\
(0.0006)\end{array}$ \\
\hline Sector Dummy & $\begin{array}{c}-0.0510^{* * *} \\
(0.0010)\end{array}$ & dropped \\
\hline Saldão & $\begin{array}{c}0.1259^{* * *} \\
(0.0012)\end{array}$ & $\begin{array}{c}-0.0037^{* * * *} \\
(0.0002)\end{array}$ \\
\hline D2 Trimester & $\begin{array}{c}-0.0335^{* * *} \\
(0.0015)\end{array}$ & $\begin{array}{c}-0.0284^{* * *} \\
(0.0003)\end{array}$ \\
\hline D3 Trimester & $\begin{array}{c}-0.1021^{* * *} \\
(0.0017)\end{array}$ & $\begin{array}{c}-0.0462^{* * *} \\
(0.0003)\end{array}$ \\
\hline D4 Trimester & $\begin{array}{c}-0.0735^{* * *} \\
(0.0019)\end{array}$ & $\begin{array}{c}-0.0873^{* * *} \\
(0.0004)\end{array}$ \\
\hline D2007 & $\begin{array}{c}-0.1085^{* * *} \\
(0.0017)\end{array}$ & $\begin{array}{c}-0.1396^{* * *} \\
(0.0005)\end{array}$ \\
\hline D2008 & $\begin{array}{c}-0.1414^{* * *} \\
(0.0017)\end{array}$ & $\begin{array}{c}-0.2521^{* * *} \\
(0.0006)\end{array}$ \\
\hline D2009 & $\begin{array}{c}-0.0981^{* * *} \\
(0.0024)\end{array}$ & $\begin{array}{c}-0.3106^{* * *} \\
(0.0007)\end{array}$ \\
\hline Constant & $\begin{array}{c}6.1493^{* * *} \\
(0.0019)\end{array}$ & $\begin{array}{c}6.5430^{* * *} \\
(0.0006)\end{array}$ \\
\hline Group variable & & Product Code \\
\hline Number of Obs & $1,379,358$ & $1,379,358$ \\
\hline Number of groups & & 765 \\
\hline Obs per Group: minimum & & 2 \\
\hline Obs per Group: average & & 1,803 \\
\hline Obs per Group: maximum & & 65,021 \\
\hline $\mathrm{F}(9.1378584)$ & $(11.1379346)=39,097$ & $(9.1378584)=26,789$ \\
\hline Prob $>$ F & 0 & 0 \\
\hline R-Squared & 0.22 & \\
\hline R-Squared: within & & 0.2437 \\
\hline R-Squared: between & & 0.0730 \\
\hline R-Squared: overall & & 0.0059 \\
\hline Root MSE & 0.64 & \\
\hline $\operatorname{Corr}\left(u_{i}, \mathrm{Xb}\right)$ & & -0.2147 \\
\hline$\sigma_{u}$ & & 0.9431 \\
\hline$\sigma_{e}$ & & 0.1055 \\
\hline$\rho$ (fraction of variance due to $u_{i}$ ) & & 0.9877 \\
\hline
\end{tabular}




\section{Table 3.5: Client's Characteristics Fixed Effect Regression Re-} SULTS

Results of the fixed effect regression on client's characteristics. IPI effect is a dummy that is one when it is IPI period and the product bought is one with the reduced tax, Product with IPI Reduction is a dummy that is one when the product bought is one with the reduced tax, IPI Reduction Period is a dummy that is one when it is IPI period, Sector Dummy is a dummy that is one when the product is form the home appliance sector, "Saldão is the exogenous variable used in the first stage(a dummy variable that is one when the month of the purchase is one of the "saldão" months, that is, when one special payment plan is also available), dummies of trimester and yearly dummies. Robust standard errors in parentheses. Significance: ${ }^{* *} \mathrm{p}<0.01 ;{ }^{* *} \mathrm{p}<0.05$ and ${ }^{*} \mathrm{p}<0.1$.

\begin{tabular}{|c|c|c|c|c|}
\hline $\begin{array}{c}\text { Estimation } \\
\text { Variable }\end{array}$ & $\begin{array}{c}\text { Age } \\
\text { Coefficient }\end{array}$ & $\begin{array}{c}\text { Gender } \\
\text { Coefficient }\end{array}$ & $\begin{array}{c}\text { Income } \\
\text { Coefficient }\end{array}$ & $\begin{array}{l}\text { Education } \\
\text { Coefficient }\end{array}$ \\
\hline IPI Effect & $\begin{array}{c}0.0568 \\
(0.0829)\end{array}$ & $\begin{array}{l}0.0046^{*} \\
(0.0028)\end{array}$ & $\begin{array}{c}0.0033 \\
(0.0052)\end{array}$ & $\begin{array}{c}0.0005 \\
(0.0041)\end{array}$ \\
\hline Product with IPI Reduction & dropped & dropped & dropped & dropped \\
\hline IPI Reduction Period & $\begin{array}{l}0.1239^{*} \\
(0.0718)\end{array}$ & $\begin{array}{c}0.0087^{* * *} \\
(0.0024)\end{array}$ & $\begin{array}{l}-0.0039 \\
(0.0046)\end{array}$ & $\begin{array}{c}0.0012 \\
(0.0036)\end{array}$ \\
\hline Sector Dummy & dropped & dropped & dropped & dropped \\
\hline Saldão & $\begin{array}{c}0.1632^{* * *} \\
(0.0284)\end{array}$ & $\begin{array}{c}0.0208^{* * *} \\
(0.0010)\end{array}$ & $\begin{array}{c}0.0159^{* * *} \\
(0.0019)\end{array}$ & $\begin{array}{c}0.0291^{* * * *} \\
(0.0014)\end{array}$ \\
\hline D2 Trimester & $\begin{array}{c}-0.1450^{* * * *} \\
(0.0358)\end{array}$ & $\begin{array}{c}-0.0096^{* * * *} \\
(0.0012)\end{array}$ & $\begin{array}{c}-0.0143^{* * *} \\
(0.0024)\end{array}$ & $\begin{array}{c}-0.0095^{* * *} \\
(0.0018)\end{array}$ \\
\hline D3 Trimester & $\begin{array}{c}0.1075^{* * *} \\
(0.0394)\end{array}$ & $\begin{array}{l}-0.0005 \\
(0.0013)\end{array}$ & $\begin{array}{c}-0.0499 * * * \\
(0.0026)\end{array}$ & $\begin{array}{c}-0.0284^{* * *} \\
(0.0020)\end{array}$ \\
\hline D4 Trimester & $\begin{array}{c}-0.2572^{* * * *} \\
(0.0434)\end{array}$ & $\begin{array}{c}0.0011 \\
(0.0015)\end{array}$ & $\begin{array}{c}-0.0485^{* * *} \\
(0.0029)\end{array}$ & $\begin{array}{c}-0.0187 * * * \\
(0.0022)\end{array}$ \\
\hline D2007 & $\begin{array}{c}-0.5321^{* * * *} \\
(0.0480)\end{array}$ & $\begin{array}{l}0.0031^{*} \\
(0.0017)\end{array}$ & $\begin{array}{c}-0.0973^{* * *} \\
(0.0034)\end{array}$ & $\begin{array}{c}-0.0414^{* * *} \\
(0.0024)\end{array}$ \\
\hline D2008 & $\begin{array}{c}-1.1971^{* * *} \\
(0.0547)\end{array}$ & $\begin{array}{l}-0.0024 \\
(0.0019)\end{array}$ & $\begin{array}{c}-0.1358^{* * *} \\
(0.0038)\end{array}$ & $\begin{array}{c}-0.0534^{* * *} \\
(0.0028)\end{array}$ \\
\hline D2009 & $\begin{array}{c}-0.9993^{* * *} \\
(0.0729)\end{array}$ & $\begin{array}{c}-0.0058^{* *} \\
(0.0025)\end{array}$ & $\begin{array}{c}-0.1542^{* * *} \\
(0.0050)\end{array}$ & $\begin{array}{c}-0.0668^{* * *} \\
(0.0036)\end{array}$ \\
\hline Constant & $\begin{array}{c}43.3714^{* * *} \\
(0.0557)\end{array}$ & $\begin{array}{c}0.6293^{* * *} \\
(0.0019)\end{array}$ & $\begin{array}{c}1.2141^{* * *} \\
(0.0039)\end{array}$ & $\begin{array}{c}1.8239^{* * *} \\
(0.0028)\end{array}$ \\
\hline Group variable & Product Code & Product Code & Product Code & Product Code \\
\hline Number of Obs & $1,379,358$ & $1,379,358$ & $1,379,358$ & $1,379,358$ \\
\hline Number of groups & 765 & 765 & 765 & 765 \\
\hline Obs per Group: minimum & 2 & 2 & 2 & 2 \\
\hline Obs per Group: average & 1,803 & 1,803 & 1,803 & 1,803 \\
\hline Obs per Group: maximum & 65,021 & 65,021 & 65,021 & 65,021 \\
\hline $\mathrm{F}(9.1378584)$ & 73 & 68 & 209 & 132 \\
\hline Prob $>$ F & 0 & 0 & 0 & 0 \\
\hline R-Squared: within & 0.0005 & 0.0004 & 0.0015 & 0.0009 \\
\hline R-Squared: between & 0.0024 & 0.0013 & 0.0225 & 0.0323 \\
\hline R-Squared: overall & 0.0005 & 0.0004 & 0.0006 & 0.0004 \\
\hline $\operatorname{Corr}\left(u_{i}, \mathrm{Xb}\right)$ & -0.0556 & -0.0165 & -0.1602 & -0.1435 \\
\hline$\sigma_{u}$ & 3.5961 & 0.1093 & 0.6095 & 0.2322 \\
\hline$\sigma_{e}$ & 13.9724 & 0.4787 & 0.9222 & 0.7010 \\
\hline$\rho$ (fraction of variance due to $\left.u_{i}\right)$ & 0.0621 & 0.0006 & 0.3040 & 0.0989 \\
\hline
\end{tabular}




\section{Bibliography}

Abbring, J. H., Heckman, J. J., Chiappori, P.-A., \& Pinquet, J. (2003). Adverse selection and moral hazard in insurance: Can dynamic data help to distinguish? Journal of European Economic Asssociation, 1, 512-521.

Adams, W., Einav, L., \& Levin, J. (2009). Liquidity constraints and imperfect information in subprime lending. American Economic Review, 99:1, 49-84.

Ausubel, L. (1999). Adverse selection in credit card markets. Working paper, University of Maryland.

Besley, T. J. \& Rosen, H. S. (1999). Sales taxes and prices: an empirical analysis. National Tax Journal, 52, 157-178.

Bhardwaj, P. (2001). Delegating pricing decisions. Marketing Science, 20, 143-169.

Borenstein, S., Cameron, A. C., \& Gilbert, R. (1997). Do gasoline prices respond asymmetrically to crude oil price changes? Quarterly Journal of Economics, 112, 305-339.

Chiappori, P.-A. \& Salanié, B. (2000). Testing for asymmetric information in insurance markets. The Journal of Political Economy, 108, 56-78.

Doyle, J. J. \& Samphantharak, K. (2008). \$2.00 gas! studying the effects of a gas tax moratorium. Journal of Public Economics, 92, 869-884.

Farrell, J. \& Shapiro, C. (2010). Recapture, pass-through, and market definition. Antitrust Law Journal, 76, 585-604.

Joseph, K. (2001). On the optimality of delegating pricing authority to the sales force. The Journal of Marketing, 65, 62-70.

Karlan, D. \& Zinman, J. (2009). Observing unobservables: Identifying information asymmetries with a consumer credit field experiment. Econometrica, 777, 1993-2008.

Kenkel, D. S. (2005). Are alcohol tax hikes fully passed throught to prices? evidence from alaska. The American Economic Review, 95, 273-277. 
Lal, R. (1986). Delegating pricing responsability to the salesforce. Marketing Science, 5, 159-168.

Mishra, B. K. \& Prasad, A. (2004). Centralized pricing versus delegating pricing to the salesforce under information asymmetry. Marketing Science, 23, 21-27.

Mishra, B. K. \& Prasad, A. (2005). Delegating pricing decisions in competitive markets with symmetric and asymmetric information. Marketing Science, 24, 490-497.

Poterba, J. M. (1996). Retail price reactions to changes in state and local sales taxes. National Tax Journal, 49, 165-176.

Primeaux, W. J. (1970). The effect of consumer knowledge and bargaining strenght on final selling price: A case study. The Journal of Business, 43, 419-426.

Silva, F. S. S. (2012). An Analysis of Car Loan Market: Judicial Efficiency, Real Business Cycles and Asymmetric Information. Phd. thesis, Pontifícia Universidade Católica do Rio de Janeiro.

Stephenson, P. R., Cron, W. L., \& Frazier, G. L. (1979). Delegating pricing authority to the sales force: The effects on sales and profit performance. The Journal of Marketing, 43, 21-28.

Weyl, E. G. \& Fabinger, M. (2012). Pass-through as an economic tool. Working paper. 